\title{
The Role of PerR in $\mathrm{O}_{2}$-Affected Gene Expression of Clostridium acetobutylicum ${ }^{\nabla} \dagger$
}

\author{
Falk Hillmann, ${ }^{1}$ Christina Döring, ${ }^{2}$ Oliver Riebe, ${ }^{1}$ Armin Ehrenreich, ${ }^{2}+$ \\ Ralf-Jörg Fischer, ${ }^{1}$ and Hubert Bahl ${ }^{1 *}$

\begin{abstract}
Abteilung Mikrobiologie, Institut für Biowissenschaften, Universität Rostock, Albert Einstein Str. 3, D-18051 Rostock, Germany, ${ }^{1}$ and Abteilung Allgemeine Mikrobiologie, Institut für Mikrobiologie und Genetik, Georg-August-Universität Göttingen, Grisebachstr. 8, D-37077 Göttingen, Germany ${ }^{2}$
\end{abstract}

Received 13 March 2009/Accepted 9 July 2009

\begin{abstract}
In the strict anaerobe Clostridium acetobutylicum, a PerR-homologous protein has recently been identified as being a key repressor of a reductive machinery for the scavenging of reactive oxygen species and molecular $\mathrm{O}_{2}$. In the absence of PerR, the full derepression of its regulon resulted in increased resistance to oxidative stress and nearly full tolerance of an aerobic environment. In the present study, the complementation of a Bacillus subtilis PerR mutant confirmed that the homologous protein from $C$. acetobutylicum acts as a functional peroxide sensor in vivo. Furthermore, we used a transcriptomic approach to analyze gene expression in the aerotolerant PerR mutant strain and compared it to the $\mathrm{O}_{2}$ stimulon of wild-type $C$. acetobutylicum. The genes encoding the components of the alternative detoxification system were PerR regulated. Only few other targets of direct PerR regulation were identified, including two highly expressed genes encoding enzymes that are putatively involved in the central energy metabolism. All of them were highly induced when wild-type cells were exposed to sublethal levels of $\mathrm{O}_{2}$. Under these conditions, $C$. acetobutylicum also activated the repair and biogenesis of DNA and Fe-S clusters as well as the transcription of a gene encoding an unknown CO dehydrogenase-like enzyme. Surprisingly few genes were downregulated when exposed to $\mathrm{O}_{2}$, including those involved in butyrate formation. In summary, these results show that the defense of this strict anaerobe against oxidative stress is robust and by far not limited to the removal of $\mathrm{O}_{2}$ and its reactive derivatives.
\end{abstract}

Although many bacteria are commonly classified as strict anaerobes, aerotolerance can vary greatly among these organisms. Some anaerobes even use catalase and superoxide dismutase as efficient $\mathrm{H}_{2} \mathrm{O}_{2}$ - and $\mathrm{O}_{2}$-scavenging enzymes, which were previously proposed to be limited exclusively to aerobes (45; for reviews, see references 6 and 32). Even when missing these two, fermentative anaerobes can often use their replete pool of reducing equivalents for the complete reduction of these molecules and $\mathrm{O}_{2}$ itself. In anaerobes in particular, the level of generation of the two major reactive oxygen species (ROS), $\mathrm{H}_{2} \mathrm{O}_{2}$ and $\mathrm{O}_{2}{ }^{-}$, is elevated during oxygen exposure due to their wide use of reduced flavins as cofactors in redox enzymes. Models for anaerobic oxygen detoxification via superoxide reductase, peroxidase, and NADH oxidases have been proposed for Pyrococcus furiosus, Desulfovibrio vulgaris, and, most recently, Clostridium acetobutylicum $(33,57,68)$. These essentially include oxygen-reducing flavodiiron proteins (FDPs), superoxide-reducing desulfoferrodoxin (Dfx), and rubrerythrins as peroxidases $(26,56,57)$. Reduced rubredoxin thereby acts as the intermediate electron carrier, the pool of which is continuously reloaded by an NADH-dependent rubre-

\footnotetext{
* Corresponding author. Mailing address: Abt. Mikrobiologie, Institut für Biowissenschaften, Universität Rostock, Albert Einstein Str. 3, D-18051 Rostock, Germany. Phone: 49-381-498-6150. Fax: 49-381498-6152. E-mail: hubert.bahl@uni-rostock.de.

† Supplemental material for this article may be found at http://jb .asm.org/.

$\$$ Present address: Lehrstuhl für Mikrobiologie, Technische Universität München, Am Hochanger 4, 85350 Freising, Germany.

${ }^{\nabla}$ Published ahead of print on 31 July 2009.
}

doxin-dependent oxidoreductase $(55,57)$. The sporulating gram-positive anaerobe Clostridium acetobutylicum is a classic example of a fermentative strict anaerobe. In the absence of oxygen, it ferments sugars to the organic acids acetate and butyrate or shifts to solvent formation with acetone and butanol as major products (for a review, see reference 13). Especially the latter one has regained attention lately as an attractive biofuel (14). Thus, metabolic engineering and in silico modeling of clostridial metabolism are ranked highly among recent efforts to increase productivity $(39,53,61,64)$. Furthermore, the sequenced genome and the design of microarrays for global-scale transcriptional analysis of $C$. acetobutylicum have substantially improved the understanding of solvent formation and allowed a detailed view on its unique life cycle $(34,50,54)$.

During exposure to sublethal $\mathrm{O}_{2}$ concentrations, C. acetobutylicum rapidly induces the expression of all components of its detoxification system and consumes dissolved $\mathrm{O}_{2}(36)$. However, when the rate of influx exceeds the rate of consumption, the organism immediately ceases its metabolic activity and resumes only after anaerobiosis is restored $(35,51)$. Studies of central redox enzymes employed by anaerobes revealed that these were highly susceptible to damage of their iron sulfur sites caused directly by molecular oxygen, e.g., pyruvate-formate lyase of Escherichia coli or pyruvate-ferredoxin oxidoreductase (PFOR) from C. acetobutylicum $(46,59)$. Bacteroides thetaiotaomicron, a gram-negative anaerobe, is even employing efficient repair mechanisms to recycle this enzyme once conditions are shifted back to anaerobiosis (52).

Altogether, these observations have established the concept that anaerobes are not primarily sensitive to oxygen due to 
TABLE 1. Bacterial strains used in this study

\begin{tabular}{|c|c|c|}
\hline Strain & Relevant characteristic(s) ${ }^{a}$ & $\begin{array}{l}\text { Reference } \\
\text { or source }\end{array}$ \\
\hline \multicolumn{3}{|l|}{ C. acetobutylicum } \\
\hline MGCcac 15 & ATCC $824 \Delta$ CAC824I & 65 \\
\hline$\Delta$ perR & MGCcac15 $\Delta$ perR $\mathrm{mls}^{+}$ & 25 \\
\hline \multicolumn{3}{|l|}{ E. coli } \\
\hline pTperR $R_{\mathrm{Cac}}$ & DH5 $\alpha$ plasmid pTperR $R_{\mathrm{Cac}} a m p^{+}$ & This study \\
\hline \multicolumn{3}{|l|}{ B. subtilis } \\
\hline HB1000 & ZB307A attSP $\beta$ & 8 \\
\hline HB1000R $\mathrm{R}_{\mathrm{Cac}}$ & HB1000 amyE::perR $R_{\mathrm{Cac}} \mathrm{cat}^{+}$ & This study \\
\hline HB0509 & HB1000 perR::spc & 7 \\
\hline $\mathrm{HB} 0509 \mathrm{R}_{\mathrm{Cac}}$ & HB0509 amyE::perR $R_{\mathrm{Cac}} \mathrm{cat}^{+}$ & This study \\
\hline
\end{tabular}

${ }^{a}$ Abbreviations: $a m p^{+}$, ampicillin resistance gene; $c a t^{+}$, chloramphenicol resistance gene; $s p c$, spectinomycin resistance gene; $m l s R^{+}$, macrolide, lincosamide, and streptogramin B resistant.

their lack or inefficiency of scavenging enzymes. Instead, central metabolic steps in anaerobic energy conversion are poisoned by molecular oxygen $(29,31)$. Therefore, it does not seem surprising that some anaerobes that are temporarily but frequently exposed to oxygen found ways to avoid these bottlenecks and direct the carbon flow onto oxygen-resistant pathways $(3,52,66)$. A similar strategy has been proposed for an oxygen-resistant mutant of $C$. acetobutylicum (31). Following the deletion of the clostridial perR homologue, the constitutive expression of its regulon resulted in drastically enhanced aerobic survival and permitted time-limited growth in an aerobic environment (25). In closely related facultative aerobes like Bacillus subtilis, the peroxide repressor PerR senses intracellular levels of $\mathrm{H}_{2} \mathrm{O}_{2}$ by metal-catalyzed histidine oxidation and controls genes for which the proteins are involved in the scavenging of hydrogen peroxide, iron storage, and DNA protection $(22,40)$. PerR regulation was also previously proposed for anaerobic sulfate reducers and was further supported by the coordinate induction of the predicted target genes in response to low oxygen concentrations with Desulfovibrio vulgaris (47, 58). The work presented here is a combined approach of microarray technology and complementational studies to obtain a global view of the organism's oxygen stimulon and refine the regulatory role of PerR in a strict anaerobe.

\section{MATERIALS AND METHODS}

Bacterial strains and culture conditions. All strains used in this study are listed in Table 1. C. acetobutylicum MGCcac15 and C. acetobutylicum $\Delta$ perR strains were stored as spore suspensions at $-20^{\circ} \mathrm{C}$ and grown in MS minimal medium as described previously (25). Growth was monitored as the optical density at a wavelength of $600 \mathrm{~nm}\left(\mathrm{OD}_{600}\right)$. Cells for RNA sampling were anaerobically grown in 1-liter serum flasks, and at an $\mathrm{OD}_{600}$ of 0.6 to 0.7 , cultures were either aerated with compressed air with a rate of 0.05 liters of air $\min ^{-1}$ or left anaerobic as a control. The concentration of dissolved $\mathrm{O}_{2}$ was measured using the WTW (Weilheim, Germany) OXI 196 oxygen meter. As a result of the continuous uptake of $\mathrm{O}_{2}$ from the growth medium, its concentration stayed essentially below the limit of detection $\left(<6.25 \mu \mathrm{mol} \mathrm{liter}^{-1}\right)$. Samples for RNA isolation were taken following $1 \mathrm{~h}$ of $\mathrm{O}_{2}$ exposure or from anaerobic controls at an OD of 0.6 to 0.8 . Escherichia coli pTper $R_{\mathrm{Cac}}$ constitutively expressing the clostridial PerR homologue was grown overnight in $500 \mathrm{ml}$ of LB medium with $100 \mu \mathrm{g} \mathrm{ml}^{-1}$ of ampicillin at $30^{\circ} \mathrm{C}$ and $120 \mathrm{rpm}$ on a rotary shaker. B. subtilis strains were grown at $30^{\circ} \mathrm{C}$ and $170 \mathrm{rpm}$ in LB medium. For cultivation on solid medium, $15 \mathrm{~g} \mathrm{liter}^{-1}$ of agar was added to the medium. To select for the $B$. subtilis perR mutant strain, $100 \mu \mathrm{g} \mathrm{ml}^{-1}$ spectinomycin was added as an antibi- otic. Complemented strains carrying the clostridial perR gene were additionally selected by the addition of $10 \mu \mathrm{g} \mathrm{ml}^{-1}$ chloramphenicol, and $0.5 \%$ (wt/vol) xylose was added to induce $C$. acetobutylicum perR $\left(\right.$ per $R_{\mathrm{Cac}}$ ) expression.

Construction of plasmids. For the heterologous overexpression of the clostridial PerR protein, its gene was PCR amplified from chromosomal DNA of $C$. acetobutylicum using oligonucleotides $\mathrm{P}$ TSH-CAC2634-BamHI (5'-AAAAGG ATCCAACGATATATCTACAA-3') and P_TSH-CAC2634-XmaI (5'-AAAAC CCGGGAGCTTTATCCTTACAG- $3^{\prime}$ ) as primers, introducing BamHI and XmaI restriction sites (underlined). Following purification and restriction, the PCR fragment was exchanged for the hydA gene in vector pThydA, described previously by Girbal et al. (20), and the resulting vector, pTperR $R_{\mathrm{Cac}}$, was transformed into $E$. coli $\mathrm{DH} 5 \alpha$ cells. Recombinant cells were selected by the addition of ampicillin and constitutively expressed PerR from the clostridial thiolase promoter with fused Strep-tagII at the C terminus for purification (see below).

For the complementation of $B$. subtilis strains, the $p e r R_{\text {Cac }}$ gene was amplified from chromosomal DNA using P_perR-pX-1 (5'-AAAAGGATTCCACGTTTT CGAAAGCAAGG-3') and P_perR-pX-2 (5'-AAAAGGATTCTTACAACTA GCAATATTTG-3'), introducing BamHI restriction sites (underlined). The amplified fragments were cloned into vector $\mathrm{pX}$, which integrates in the amyE locus of $B$. subtilis and allows the xylose-inducible expression of proteins (37). The recombinant vector was transformed into $B$. subtilis strains HB1000 (wild type) and HB0509 (perR mutant) using a method described previously by Cutting and Youngman (10). Positive transformants were selected due to their resistance to $10 \mu \mathrm{g} \mathrm{ml}^{-1}$ of chloramphenicol.

RNA isolation and labeling. C. acetobutylicum cell samples for the isolation of total RNA were pelleted by centrifugation, immediately shock-frozen in liquid $\mathrm{N}_{2}$, and stored at $-70^{\circ} \mathrm{C}$. RNA was isolated using a modified hot-phenol procedure described previously by Fischer et al. (17). To avoid DNA contamination, isolated RNA was digested with $20 \mathrm{U}$ of RNase-free DNase (Amersham Pharmacia Biotech, Freiburg, Germany) in a total volume of $50 \mu \mathrm{l}$ and incubated for $30 \mathrm{~min}$ at $37^{\circ} \mathrm{C}$. The RNA was cleared from DNase by an addition of $15 \mu \mathrm{l}$ of 2 $\mathrm{M}$ sodium acetate ( $\mathrm{pH}$ 5.2), additional treatment with phenol, and precipitation with ethanol. Dried RNA was dissolved in $30 \mu \mathrm{l}$ of $\mathrm{H}_{2} \mathrm{O}$, and the quality of these preparations was controlled by electrophoresis in agarose gels. The integrity of RNA was additionally controlled in a BioAnalyzer (Agilent, Böblingen, Germany) run. For the preparation of labeled cDNA, $15 \mu \mathrm{g}$ random hexamer primer was annealed in a volume of $10 \mu \mathrm{l}$ to $25 \mu \mathrm{g}$ of RNA by incubation at $70^{\circ} \mathrm{C}$ for 10 min. Next, $1 \mathrm{mM}$ dATP, dTTP, and dGTP as well as $0.4 \mathrm{mM} \mathrm{dCTP,} 50 \mu \mathrm{M} \mathrm{Cy3-}$ or Cy5-labeled dCTP (GE-Healthcare, Munich, Germany), $10 \mathrm{mM}$ dithiothreitol, and 200 U SuperScript III reverse transcriptase (Invitrogen, Carlsbad, CA) were added to the mixtures, and the labeling reaction mixtures with a total volume of $20 \mu \mathrm{l}$ were incubated for 2 to $3 \mathrm{~h}$ at $42^{\circ} \mathrm{C}$. RNA was removed from the formed heteroduplexes by the addition of $2 \mu \mathrm{l} 2.5 \mathrm{M} \mathrm{NaOH}$ and incubation for $15 \mathrm{~min}$ at $37^{\circ} \mathrm{C}$. Hydrolysis was stopped by the addition of $10 \mu 12 \mathrm{M}$ HEPES (pH 7.0). Labeled cDNA was separated from the reaction mixture using GFX columns (GE-Healthcare, Munich, Germany) according to the supplier's instructions, with the only modification of washing the columns four times before elution of labeled cDNA. The incorporation of Cy3 or Cy5 was checked qualitatively by a spectrophotometric wavelength scan and was quantified by using molar extinction coefficients of 150,000 liters $\mathrm{mol}^{-1} \mathrm{~cm}^{-1}$ (at $550 \mathrm{~nm}$ ) for Cy3 and 250,000 liters $\mathrm{mol}^{-1} \mathrm{~cm}^{-1}$ (at $650 \mathrm{~nm}$ ) for Cy5.

Microarray analysis. The $C$. acetobutylicum array was constructed by spotting 5' amino-C6-modified oligonucleotides with a length of 60 to 70 bases on CodeLink microarray slides (SurModics) using a MicroGrid II microarray spotter (Zinsser Analytic, Frankfurt, Germany). Oligonucleotides were covalently coupled to the slides surface. The array contained two identical sets of 3,840 oligonucleotides representing $99.8 \%$ of all annotated open reading frames (ORFs) in C. acetobutylicum. Before hybridization, samples were denatured by incubation at $98^{\circ} \mathrm{C}$ for 5 min. The hybridization was done using Tom Freeman hybridization buffer (18) for $15 \mathrm{~h}$ at $45^{\circ} \mathrm{C}$ with cDNA containing approximately 80 pmol of Cy3 and Cy5 in an automatic Lucidea slide processor (GE-Healthcare, Munich, Germany). Slides were washed using a program applying consecutive washes two times with $1 \times \mathrm{SSC}$ buffer $(1 \times \mathrm{SSC}$ is $0.15 \mathrm{M} \mathrm{NaCl}$ plus 0.015 $\mathrm{M}$ sodium citrate) containing $0.2 \%$ sodium dodecyl sulfate (SDS) and then with $0.1 \times$ SSC. At the end, flushing of the hybridization chambers with isopropanol and evaporating of the isopropanol, which air dried the slides, were performed. Scanning was done using a GenePix 4000B microarray scanner (Molecular Devices, Canada) using GenePix Pro 6.0 software. Normalization was done by setting the arithmetic mean of the ratios equal to 1 . Only features with fluorescence greater than the local background plus 1 standard deviation were included in the analysis. To correct for features with irregular spot morphology, only those where the ratio of medians, the ratio of means, and the regression ratio differed by less than $30 \%$ were included. 
RNA was isolated from three independent cultures of C. acetobutylicum MGCcac15, which were either left anaerobic or exposed to air. RNA of the perR mutant was derived from three anaerobically growing cultures of the $C$. acetobutylicum $\Delta$ perR strain. RNA from $C$. acetobutylicum from anaerobic cultures was compared to RNA derived from aerated samples of the same strain and to RNA derived from anaerobic cultures of the C. acetobutylicum $\Delta$ perR strain. To avoid dye-specific effects, RNA from each sample was labeled with both dyes, and dye-swap experiments were performed. Resulting from these four technical replicates for each of the three independent cultures, a total of 12 sets of transcriptional data were obtained for each gene. The differential expression of an ORF was regarded as being significant when the average value of the ratio median from at least eight data points was either $\geq 2$ or $\leq 0.5$. Full lists of transcribed genes, functional information, and regulation under $\mathrm{O}_{2}$ or in perRdeleted cells are available in Tables S1 and S2 in the supplemental material. Microarray design and data are also available from the ArrayExpress database under accession no. A-MEXP-1561 (http://www.ebi.ac.uk/microarray-as/aer /entry). Microarray results for three genes for which transcription has not been previously identified to be either $\mathrm{O}_{2}$ or PerR responsive were validated by semiquantitative reverse transcription-PCR. The expression ratios of CAC0116, CAC2459, and CAC3657 detected by reverse transcription-PCR corresponded with those obtained by microarray analysis (see Fig. S1 in the supplemental material).

Promoter analysis and motif identification. The Virtual Footprint software linked to the PRODORIC database (http://prodoric.tu-bs.de/vfp) (48) of gene regulation and gene expression in prokaryotes was used to identify DNA regions with a high level of similarity to the proposed regulatory motif IR2. The sequenced genome of $C$. acetobutylicum including megaplasmid pSOL1 was searched for the palindrome nucleotide sequence 5'-AATNNNTATTANNTA ATANNNATT-3', with "N" representing any type of nucleotide and allowing one mismatch. The search pattern was identified in 13 different positions on the chromosome. Two sites were located in the coding region of genes and 11 sites were in the $5^{\prime}$ noncoding region of genes within a 250-bp distance to the starting codon. Motifs with three mismatches were also identified in the upstream region of two other highly upregulated genes. A sequence logo representing a multilevel consensus sequence for each motif was achieved by an alignment of these sequences using Weblogo software (http://www.weblogo.berkeley.edu) (9).

Heterologous overexpression and protein purification. PerR from C. acetobutylicum was heterologously expressed as a Strep-tagII fusion protein in E. coli cells carrying plasmid pTper $R_{\mathrm{Cac}}$. Strep-tagII is an eight-residue minimal peptide sequence composed of Trp-Ser-His-Pro-Gln-Phe-Glu-Lys (IBA GmbH, Göttingen, Germany), which binds to streptavidin and allows protein purification using streptactin affinity chromatography (60). Cells were harvested by centrifugation and washed in $50 \mathrm{mM}$ Tris $\mathrm{HCl}$ buffer $(\mathrm{pH} 8.0)$ with $150 \mathrm{mM} \mathrm{NaCl}$ and $1 \mathrm{mM}$ EDTA. Pellets were either stored for up to 7 days at $-20^{\circ} \mathrm{C}$ or immediately used as a source of protein. All further purification steps for the heterologous protein used in this study were carried out as described previously (56). The protein content in the elution fractions was determined using the Bradford assay (5).

Electrophoretic mobility shift assay. A DNA fragment of the $r b r 3 A-r b r 3 B$ promoter region, covering the last 235 bp of the $r b r 3 A 5^{\prime}$ untranslated region, was PCR amplified using oligonucleotides P_3p_rbr3A (5'-AGTGTCTGCAGAAG CAGGGAAAAG- $\left.3^{\prime}\right)$ and P_5p_rbr3A (5'-AATTTTCTAGATTAATCTCTCT CA- $\left.3^{\prime}\right)$ as primers. Reactions were carried out with Pwo DNA polymerase (Peqlab, Erlangen, Germany) with chromosomal DNA from C. acetobutylicum ATCC 824 as a template. PCR products were purified from agarose gels with the Nucleospin Extract II kit (Macherey-Nagel, Düren, Germany) and 3' digoxigenin labeled using the DIG gel shift kit (second generation; Roche Applied Science, Mannheim, Germany) according to the manufacturer's instructions. Labeled promoter fragments $(12.5 \mathrm{nM})$ were incubated for $20 \mathrm{~min}$ at room temperature

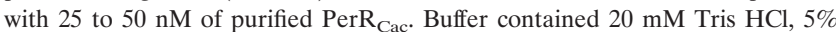
glycerol, $5 \mathrm{ng} \mathrm{Hl}^{-1}$ salmon sperm DNA, $50 \mathrm{ng} \mathrm{\mu l}^{-1}$ bovine serum albumin, 50 $\mathrm{mM} \mathrm{KCl}$, and $100 \mu \mathrm{M} \mathrm{MnCl}_{2}$. Unlabeled fragments were added as controls for specific binding to DNA. The reaction mixtures were applied to $1.5 \%$ (wt/vol) agarose gels with $0.5 \times$ TBE (44.5 mM Tris- $\mathrm{HCl}$ [pH 8.0], $44.5 \mathrm{mM}$ boric acid, 5 mM EDTA) as a running buffer. Electrophoreses were run at room temperature for 1 to $1.5 \mathrm{~h}$ at $65 \mathrm{~V}$, and the DNA fragments were blotted onto nylon membranes (Nytran SuPerCharge nylon transfer membrane, $0.45-\mu \mathrm{m}$ pore size; Schleicher \& Schuell Bioscience, Dassel, Germany). The detection of the digoxigenin-labeled DNA was performed as described previously (44).

Zone-of-inhibition assay. To determine the sensitivity to $\mathrm{H}_{2} \mathrm{O}_{2}$, a zone-ofinhibition assay was performed essentially as described previously by Bsat et al. (7). Fresh LB medium $(50 \mathrm{ml})$ with the appropriate antibiotics was inoculated with $B$. subtilis from cultures grown overnight, and cells were grown at $30^{\circ} \mathrm{C}$ at $170 \mathrm{rpm}$ on a rotary shaker to the mid-logarithmic growth phase $\left(\mathrm{OD}_{600}\right.$ of 0.4 to 0.5$)$. Aliquots of $1 \mathrm{ml}$ were added to $15 \mathrm{ml}$ of prewarmed $\left(45^{\circ} \mathrm{C}\right) \mathrm{LB}$ medium containing $1.5 \%(\mathrm{wt} / \mathrm{vol})$ agar without antibiotics. The cell suspension was poured into agar plates, and after hardening, 5-mm filter paper discs containing $5 \mu \mathrm{l}$ of $1 \mathrm{M} \mathrm{H}_{2} \mathrm{O}_{2}$ were placed onto the agar plates. Growth and zones of inhibition for each strain were monitored following overnight incubation at $30^{\circ} \mathrm{C}$. Each strain was analyzed in triplicate. Results for each strain were reproducible within a range of $\pm 15 \%$ of the maximum diameter of the inhibition zone.

Measurement of catalase activity. $B$. subtilis cells were grown to the late exponential growth phase $\left(\mathrm{OD}_{600}\right.$ of 1.0 to 1.2$)$ in $\mathrm{LB}$ medium and harvested by centrifugation. Pellets were stored at $-20^{\circ} \mathrm{C}$ or immediately used for the preparation of crude extracts. Cells were disrupted by sonication at $4^{\circ} \mathrm{C}$ using the Ultraschall Desintegrator Sonopuls HD60 apparatus (Medizin und Labortechnik, Hamburg, Germany), and undisrupted cells and cell debris were removed by centrifugation at $15,000 \times g$ for $30 \mathrm{~min}$. The protein concentration in the obtained cell extracts was determined with the Bradford assay (5). Catalase activity was measured spectrophotometrically at a wavelength of $240 \mathrm{~nm}$. Different amounts of enzyme were added to $50 \mathrm{mM}$ potassium phosphate buffer $(\mathrm{pH} 7.0)$ at $25^{\circ} \mathrm{C}$ and blanked. The reaction was started by the addition of $\mathrm{H}_{2} \mathrm{O}_{2}$ to the mixture up to a final concentration of $25 \mathrm{mM}$. The decrease in absorbance was monitored over time using an Ultrospec 3000 spectrophotometer (Pharmacia Biotech, Germany). One unit of catalase activity was defined as the amount of enzyme that decomposes $1 \mu \mathrm{mol}$ of $\mathrm{H}_{2} \mathrm{O}_{2} \mathrm{~min}^{-1}$ using an $\varepsilon_{240}$ value of $43.6 \mathrm{mM}^{-1} \mathrm{~cm}^{-1}$.

\section{RESULTS}

Oxygen leads to a global transcriptional response in $C$. acetobutylicum. To identify $\mathrm{O}_{2}$-inducible genes, anaerobic cultures of $C$. acetobutylicum were sparged with compressed air at a rate of 0.05 liters $\min ^{-1}$ liter $^{-1}$ culture volume during the logarithmic growth phase. As a result of continuous uptake, the $\mathrm{O}_{2}$ concentration remained below detection limits $(<6.25$ $\mu \mathrm{mol}$ liter $^{-1}$ ), and growth continued at essentially the same rate (data not shown), which reflects previously reported results $(35,51)$. Samples for the analysis of global transcription were taken following $1 \mathrm{~h}$ of microaerobiosis during the exponential growth phase. The level of gene expression of aerated cells was compared to that of a parallel culture that was left anaerobic. Oxygen exposure drastically affected (more than threefold) the transcription of 76 genes, resulting in 60 genes which were induced and 16 genes which were downregulated. The cluster of orthologous groups (COG) classification of proteins allowed a first functional overview of the products of all genes that were differentially expressed (more than twofold) upon exposure to $\mathrm{O}_{2}$ (67) (Fig. 1a). However, a large proportion (27\% of the upregulated genes and $20 \%$ of the downregulated genes) encoded proteins that could not be grouped or were of unknown function (cluster $\mathrm{X}$ ). The most dramatic changes occurred with genes with proteins belonging to $\mathrm{COG}$ clusters $\mathrm{C}$ (energy production and conversion; 12\% upregulated and 14\% downregulated genes), E (amino acid transport and metabolism; $11 \%$ and $2 \%$, respectively), $\mathrm{G}$ (carbohydrate metabolism and transport; $3 \%$ and $11 \%$, respectively), $\mathrm{H}$ (coenzyme transport and metabolism; $3 \%$ and $11 \%$, respectively), and $\mathrm{P}$ (inorganic ion transport; 5\% and 9\%, respectively). Overall, theses changes in global transcription suggested that C. acetobutylicum actively reacts to oxygen in the environment by concentrating its energy resources on the protection of essential metabolic pathways, maintenance of a reducing interior, and detoxification of ROS.

Proteins involved in detoxification and redox balance. The group of genes that were highly activated included all those which encoded the proteins previously characterized as being components of an ROS detoxification pathway or as part of an oxygen-responsive gene cluster $(25,36,57)$. These include, 


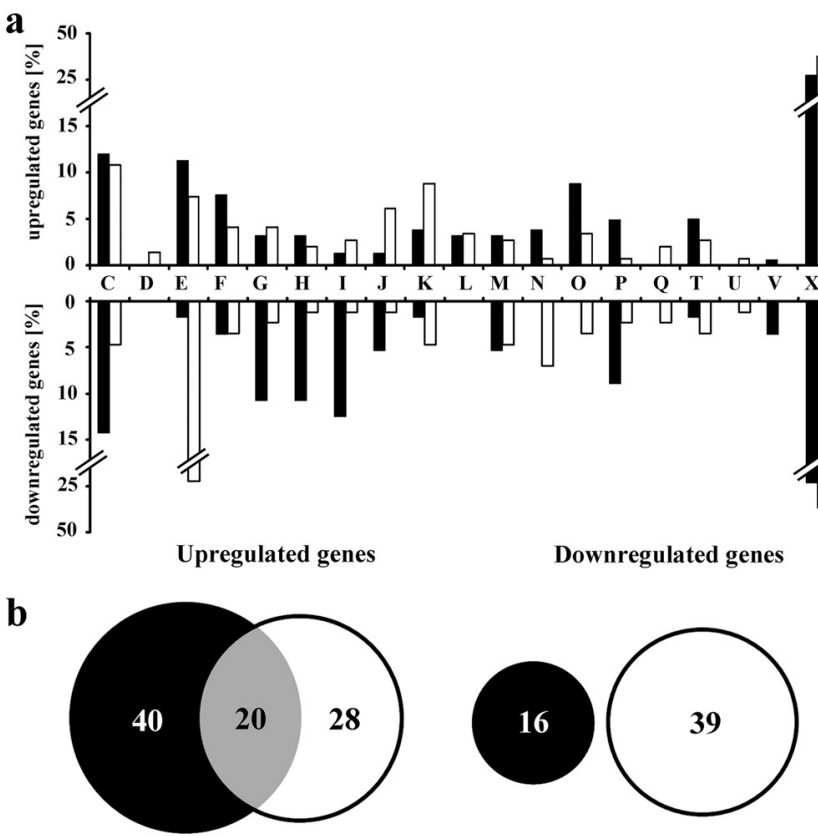

FIG. 1. Global transcriptional changes in wild-type C. acetobutylicum upon exposure to $\mathrm{O}_{2}$ and in C. acetobutylicum lacking PerR. (a) The protein products of all differentially regulated genes (more than twofold) were grouped according to the COG classification scheme. Black and shaded columns indicate $\mathrm{O}_{2}$ - and PerR-responsive genes, respectively. The COG designations are as follows: $\mathrm{C}$, energy; $\mathrm{D}$, cell cycle control, cell division; E, amino acid metabolism and transport; F, nucleotide metabolism and transport; $\mathrm{G}$, carbohydrate metabolism and transport; $\mathrm{H}$, coenzyme metabolism and transport; I, lipid metabolism; J, translation; K, transcription and regulation; $\mathrm{L}$, replication, recombination, and repair; $\mathrm{M}$, cell wall and membrane proteins; $\mathrm{N}$, cell motility; $\mathrm{O}$, protein fate and chaperones; $\mathrm{P}$, inorganic ion metabolism and transport; $\mathrm{Q}$, secondary metabolites; T, signal transduction; $\mathrm{U}$, secretion and intracellular trafficking; V, defense; X, poorly characterized or no cluster. (b) Venn diagrams illustrating the overlapping (gray) threefold induction (left) or threefold repression (right) of members of the oxygen stimulon (black circles) and the PerR regulon (white circles).

namely, reverse rubrerythrins ( $r b r 3 A-r b r 3 B)$, desulfoferrodoxin $(d f x)$, rubredoxin $(r d)$, NADH-dependent rubredoxin oxidoreductase (NROR), and the oxygen-reducing FDPs FprA1 and FprA2 (Table 2). High levels of expression of these genes represented an efficient indicator that the global transcriptional changes observed resulted from intense oxidative stress as result of $\mathrm{O}_{2}$ exposure. Other strongly activated genes whose products play a central role in the cell's redox balance included glutaredoxin- and thioredoxin-dependent systems (Table 2). The relatively large number of homologues and associated peroxidases suggests a vital role during oxidative stress. Interestingly, significant transcriptional changes under these conditions were not observed for the two annotated superoxide dismutases of the $\mathrm{Cu} / \mathrm{Zn}(\mathrm{CAC} 2567)$ and $\mathrm{Fe} / \mathrm{Mn}$ (CAC1363) types. Furthermore, the transcription of the rubrerythrins Rbr1 and Rbr2, which are characterized by their N-terminal ferritinlike domains, and the rubredoxin-like domains on the $\mathrm{C}$ terminus also did not respond to the presence of $\mathrm{O}_{2}$ (Table 2).

Nucleic acid repair and iron uptake. Anaerobes in particular are highly susceptible to oxidative damage to proteins and DNA via a direct $\mathrm{O}_{2}$-dependent inactivation of $\mathrm{Fe}$-S clusters or Fenton-type chemistry (30). A more detailed view of the oxy- gen stimulon revealed that $C$. acetobutylicum not only induces the active detoxification of oxygen and reactive derivatives but also prompts the repair of essential cellular components. The repair of damaged DNA is activated by an induced transcription of genes encoding enzymes involved in the de novo synthesis of nucleotides, e.g., enzymes of the purine metabolism (CAC1390 to CAC1395 and CAC1655) and three ribonucleotide diphosphate reductases (CAC1047, CAC3276, and CAC3277), as well as those responsible for excision and replacement ( $u v r A$ and $u v r B$ [CAC0502 and CAC0503, respectively]) (Table 2). As expected from the conflictive role of iron as a cofactor in defense enzymes and a catalyst in Fenton chemistry, iron uptake genes were strictly regulated upon exposure to oxygen. Two Feo-type uptake systems for $\mathrm{Fe}^{2+}$ and one ferrichrome-dependent system were upregulated (CAC0447 and CAC0448, CAC0788 to CAC0791, and CAC1029 to CAC1032), which could support the induced Suf and Nif machinery (CAC3288 to CAC3292) in the biogenesis of $\mathrm{Fe}-\mathrm{S}$ clusters. Under the same conditions, a large operon (CAC1988 to CAC1994) that is putatively involved in the uptake of $\mathrm{Fe}^{3+}$ and molybdenum cofactor synthesis was repressed (Table 2). Reduced iron might become scarce due to an increasing level of production of reverse rubrerythrins and FDPs, but at this point, the differential regulation of $\mathrm{Fe}^{2+}$ and $\mathrm{Fe}^{3+}$ cannot be fully explained. Previous studies with $E$. coli have shown that moa genes for molybdenum cofactor production are enhanced under anaerobic conditions and underlie the control of the anaerobic activator protein FNR $(1,63)$. Molybdenum cofactors are known to catalyze reactions of the carbon, sulfur, and nitrogen cycles and act as sites of substrate binding and reduction in nitrogenases $(38,62)$.

Enzymes involved in central metabolism and energy conversion. An $\mathrm{O}_{2}$-sensitive PFOR, encoded by CAC2229 and CAC2499, is the central metabolic enzyme in C. acetobutylicum (46). Interestingly, the transcription of genes encoding the two subunits of an alternative $\alpha$-ketoacid ferredoxin oxidoreductase (ofrB and ofrA [CAC2458 and CAC2459, respectively]) is highly induced under oxidative conditions (Table 2). The clostridial enzyme has not been studied thus far, but previously reported studies of related enzymes from the aerobic archaea Sulfolobus sp. strain 7 and Aeropyrum pernix demonstrated a wide substrate spectrum for ketoacids and, even more importantly, aerobic stability $(49,70)$. It is therefore likely that an oxygen-labile PFOR is replaced by an oxygen-resistant enzyme to feed the pool of acetyl coenzyme A (CoA).

The megaplasmid-carried sol operon (CAP0162 to CAP0164) was slightly upregulated upon exposure to $\mathrm{O}_{2}$ (Table 2). Its protein products are thought to be involved in the early phase of solvent formation (15). Essentially all other genes whose proteins are assigned to function downstream of acetyl-CoA in the formation of butyrate are moderately downregulated (two- to fivefold) under these conditions. There are two other enzymes that are activated by $\mathrm{O}_{2}$ and for which a central role in carbon metabolism is apparent (Table 2): one is the nonphosphorylating NADP-dependent glyceraldehyde-3-phosphate dehydrogenase (GAPDH) (GapN), catalyzing the NADP-dependent oxidation from glyceraldehyde-3-phosphate to 3-phosphoglycerate (28). Supporting its functional role during glycolysis, genes encoding the enzymes responsible for the subsequent reactions in this pathway (triosephophateisomerase, phosphoglyceromutase, and eno- 
TABLE 2. Relative transcript levels of selected genes of wild-type C. acetobutylicum during oxygen exposure $\left(\mathrm{O}_{2}\right)$ and of anaerobic C. acetobutylicum lacking PerR

\begin{tabular}{|c|c|c|c|c|c|c|}
\hline \multirow[b]{2}{*}{ ORF and function ${ }^{a}$} & \multirow[b]{2}{*}{ Gene } & \multirow[b]{2}{*}{ Protein function } & \multirow{2}{*}{$\begin{array}{l}\text { COG } \\
\text { class }\end{array}$} & \multicolumn{2}{|c|}{ Fold regulation } & \multirow{2}{*}{$\begin{array}{l}\text { PerR } \\
\text { box }^{b}\end{array}$} \\
\hline & & & & $\mathrm{O}_{2}$ & $\begin{array}{c}\text { Lacking } \\
\text { PerR }\end{array}$ & \\
\hline \multicolumn{7}{|c|}{ Detoxification/redox balance } \\
\hline $\mathrm{CAC} 0327$ & $b c p$ & Bacterioferritin comigratory protein, akylhydroperoxidase & $\mathrm{O}$ & 5.2 & 16.0 & + \\
\hline САC0869 & & Thioredoxin reductase & $\mathrm{O}$ & 4.9 & 8.1 & - \\
\hline CAC1027 & fprA1 & Flavoprotein FprA1 & $\mathrm{C}$ & 4.4 & 16.1 & + \\
\hline CAC1363 & $\operatorname{sod} C$ & Superoxide dismutase; $\mathrm{Cu} / \mathrm{Zn}$ family & $\mathrm{P}$ & & 0.21 & - \\
\hline CAC1547 & $\operatorname{tr} x A$ & Thioredoxin & $\mathrm{O}$ & 7.5 & & - \\
\hline CAC1548 & $\operatorname{trx} B$ & Thioredoxin reductase & $\mathrm{O}$ & 10.3 & & - \\
\hline CAC1549 & bsaA1 & Glutathione peroxidase & $\mathrm{O}$ & 23.3 & & - \\
\hline CAC1570 & bsaA2 & Glutathione peroxidase & $\mathrm{O}$ & 2.6 & 0.1 & - \\
\hline CAC1571 & bsaA3 & Glutathione peroxidase & $\mathrm{O}$ & 5.1 & & - \\
\hline CAC2448 & nror & NROR & $\mathrm{C}$ & 7.8 & 16.8 & + \\
\hline CAC2449 & fprA2 & Flavoprotein FprA2 & $\mathrm{C}$ & 7.3 & 22.5 & + \\
\hline CAC2450 & $d f x$ & desulfoferrodoxin, superoxide reductase & $\mathrm{C}$ & 18.4 & 29.6 & + \\
\hline CAC 2567 & sod & Superoxide dismutase; Fe/Mn family & $\mathrm{P}$ & & & - \\
\hline CAC2575 & rbr1 & Rubrerythrin & $\mathrm{C}$ & & 0.42 & - \\
\hline CAC2777 & & Glutaredoxin & $\mathrm{O}$ & 3.5 & 6.0 & + \\
\hline CAC2778 & $r d$ & Rubredoxin & $\mathrm{C}$ & 5.2 & 14.4 & + \\
\hline CAC3018 & $r b r 2$ & Rubrerythrin & & & & - \\
\hline CAC3306 & $t p x$ & Thiolperoxidase & $\mathrm{O}$ & 3.0 & 3.4 & + \\
\hline CAC3597 & $r b r 3 B$ & Reverse rubrerythrin & $\mathrm{C}$ & 5.6 & 26.9 & + \\
\hline \multicolumn{7}{|l|}{ Iron metabolism/transport } \\
\hline CAC0447 & feoA1 & FeoA protein; involved in $\mathrm{Fe}^{2+}$ transport & $\mathrm{P}$ & 2.3 & & - \\
\hline CAC0448 & feoB2 & $\mathrm{Fe}^{2+}$ transport protein $\mathrm{B}(\mathrm{FeoB} 2)$ & $\mathrm{P}$ & 2.8 & & - \\
\hline CAC0788 & & Ferrichrome transport permease & $\mathrm{P}$ & 3.3 & & - \\
\hline CAC0789 & $f h u B$ & Permease & $\mathrm{P}$ & 3.4 & & - \\
\hline CAC0790 & fhuD & Ferrichrome-binding periplasmic protein & $\mathrm{P}$ & 2.6 & & - \\
\hline CAC0791 & fhuC & Ferrichrome $\mathrm{ABC}$ transporter; ATP-binding protein & $\mathrm{P}$ & 2.3 & & - \\
\hline CAC1029 & & FeoA-like protein; involved in iron transport & $\mathrm{P}$ & 5.8 & & - \\
\hline CAC1030 & & FeoA-like protein; involved in iron transport & $\mathrm{P}$ & 8.1 & & - \\
\hline CAC1031 & & FeoB-like GTPase; responsible for iron uptake & $\mathrm{P}$ & 15.9 & & - \\
\hline CAC1032 & & Predicted transcriptional regulator & $\mathrm{K}$ & 4.3 & & - \\
\hline CAC1988 & & Ferrichrome-binding periplasmic protein & $\mathrm{P}$ & 0.27 & & - \\
\hline CAC1989 & & ABC-type $\mathrm{Fe}^{3+}$ transport system, ATPase component & $\mathrm{P}$ & 0.27 & & - \\
\hline CAC1990 & & ABC-type $\mathrm{Fe}^{3+}$ transport system, permease component & $\mathrm{P}$ & 0.30 & & - \\
\hline CAC1991 & & Uncharacterized protein, YIIM family & $\mathrm{S}$ & 0.32 & & - \\
\hline CAC1992 & mоаC & Mo cofactor biosynthesis protein $\mathrm{C}$ & $\mathrm{H}$ & 0.30 & & - \\
\hline CAC1993 & mоaA & Mo cofactor biosynthesis protein A & $\mathrm{H}$ & 0.30 & & - \\
\hline CAC1994 & $m o a B$ & Molybdopterin biosynthesis enzyme & $\mathrm{H}$ & 0.32 & & - \\
\hline CAC1995 & & Hypothetical protein & $\mathrm{X}$ & 0.31 & & - \\
\hline CAC1996 & & Hypothetical protein & $\mathrm{X}$ & 0.36 & & - \\
\hline \multicolumn{7}{|c|}{ Nucleic acid repair/metabolism } \\
\hline CAC0502 & $u v r B$ & Excinuclease $\mathrm{ABC}$ subunit $\mathrm{B}$ & $\mathrm{L}$ & 2.1 & & - \\
\hline CAC0503 & uvrA & Excinuclease $\mathrm{ABC}$ subunit A (ATPase) & $\mathrm{L}$ & 4.2 & & - \\
\hline CAC1047 & & Ribonucleotide-diphosphate reductase $\alpha$ subunit & $\mathrm{F}$ & 9.9 & & - \\
\hline CAC1390 & purE & Phosphoribosylaminoimidazole carboxylase catalytic subunit & $\mathrm{F}$ & 3.2 & & - \\
\hline CAC1391 & purC & Phosphoribosylaminoimidazole-succinocarboxamide synthase & $\mathrm{F}$ & 3.1 & & - \\
\hline CAC1392 & purF & Amidophosphoribosyltransferase & $\mathrm{F}$ & 2.8 & & - \\
\hline CAC1393 & purM & Phosphoribosylaminoimidazole synthetase & $\mathrm{F}$ & 2.9 & & - \\
\hline CAC1394 & $\operatorname{purN}$ & Phosphoribosylglycinamide formyltransferase & $\mathrm{F}$ & 2.8 & & - \\
\hline CAC1395 & purH & $\begin{array}{l}\text { Phosphoribosylaminoimidazolecarboxamide } \\
\text { formyltransferase/IMP cyclohydrolase }\end{array}$ & $\mathrm{F}$ & 2.5 & & - \\
\hline CAC1655 & purQ-purL & Bifunctional phosphoribosylformylglycinamidine synthase & $\mathrm{F}$ & 3.5 & & - \\
\hline CAC1815 & recA & Recombinase A & $\mathrm{L}$ & 4.0 & & - \\
\hline CAC1856 & & RNase HI & $\mathrm{R}$ & 2.4 & 4.4 & - \\
\hline CAC3276 & $n r d B$ & Ribonucleotide-diphosphate reductase $\beta$ subunit & $\mathrm{F}$ & 13.5 & & - \\
\hline CAC3277 & $\operatorname{nrdA}$ & Ribonucleotide-diphosphate reductase $\alpha$ subunit & $\mathrm{F}$ & 6.5 & & - \\
\hline CAC3358 & dam & Site-specific DNA methylase & $\mathrm{L}$ & 6.4 & & \\
\hline CAC3499 & & Predicted endonuclease & G & 5.3 & 4.1 & - \\
\hline \multicolumn{7}{|l|}{ Protein turnover/repair } \\
\hline CAC1857 & & Metal-dependent peptidase & $\mathrm{S}$ & 2.2 & 4.8 & - \\
\hline CAC3288 & sufC & Fe-regulated $\mathrm{ABC}$ transporter ATPase subunit & $\mathrm{O}$ & 2.8 & & - \\
\hline
\end{tabular}


TABLE 2-Continued

\begin{tabular}{|c|c|c|c|c|c|c|}
\hline \multirow[b]{2}{*}{ ORF and function ${ }^{a}$} & \multirow[b]{2}{*}{ Gene } & \multirow[b]{2}{*}{ Protein function } & \multirow[b]{2}{*}{$\begin{array}{l}\text { COG } \\
\text { class }\end{array}$} & \multicolumn{2}{|c|}{ Fold regulation } & \multirow[b]{2}{*}{$\begin{array}{c}\text { PerR } \\
\text { box }^{b}\end{array}$} \\
\hline & & & & $\mathrm{O}_{2}$ & $\begin{array}{c}\text { Lacking } \\
\text { PerR }\end{array}$ & \\
\hline CAC3289 & sufB1 & Fe-regulated ABC-type transporter membrane component & $\mathrm{O}$ & 2.9 & & - \\
\hline CAC3290 & sufB2 & Fe-regulated $\mathrm{ABC}$-type transporter membrane component & $\mathrm{O}$ & 3.3 & & - \\
\hline CAC3291 & & Selenocysteine lyase, NifS family & $\mathrm{E}$ & 2.6 & & - \\
\hline CAC3292 & & NifU homolog involved in Fe-S cluster formation & $\mathrm{C}$ & 2.0 & & - \\
\hline CAC3624 & & 6-Pyruvoyl-tetrahydropterin synthase & $\mathrm{H}$ & 8.2 & & - \\
\hline CAC3625 & & Fe-S oxidoreductase of MoaA family & $\mathrm{O}$ & 3.1 & & - \\
\hline \multicolumn{7}{|l|}{ Energy conversion } \\
\hline CAP0162 & $\operatorname{adhE1}$ & Aldehyde dehydrogenase $\left(\mathrm{NAD}^{+}\right)$ & $\mathrm{C}$ & 1.9 & 2.2 & - \\
\hline CAP0163 & $\operatorname{ctf} A$ & Butyrate-acetoacetate CoA-transferase subunit A & $\mathrm{C}$ & 1.9 & 2.1 & - \\
\hline CAP0164 & $\operatorname{ctfB}$ & Butyrate-acetoacetate CoA-transferase subunit B & $\mathrm{C}$ & 2.0 & 2.2 & - \\
\hline CAC0116 & & CO dehydrogenase; beta chain & $\mathrm{C}$ & 23.9 & 0.05 & - \\
\hline CAC0587 & & Flavodoxin & $\mathrm{C}$ & 11.4 & & - \\
\hline CAC0711 & tpi & Triosephosphate isomerase & G & 2.1 & 3.2 & - \\
\hline CAC0712 & pgm & Phosphoglyceromutase & G & 2.8 & 9.0 & - \\
\hline CAC0713 & eno & Phosphopyruvate hydratase & G & 3.3 & 6.9 & - \\
\hline CAC2452 & & Flavodoxin & $\mathrm{C}$ & 3.6 & 11.6 & + \\
\hline CAC2458 & ofrB & 2-Oxoglutarate ferredoxin oxidoreductase, $\beta$-subunit & $\mathrm{C}$ & 9.3 & 40.0 & + \\
\hline CAC2459 & ofrA & 2-Oxoacid ferredoxin oxidoreductase, $\alpha$-subunit & $\mathrm{C}$ & 9.1 & 23.8 & + \\
\hline CAC2499 & & Pyruvate ferredoxin oxidoreductase & $\mathrm{C}$ & & 0.3 & - \\
\hline CAC2708 & hbd & 3-Hydroxybutyryl-CoA dehydrogenase & I & 0.34 & & - \\
\hline CAC2709 & etf $A$ & Electron transfer flavoprotein $\alpha$-subunit & $\mathrm{C}$ & 0.29 & & - \\
\hline CAC 2710 & etfB & Electron transfer flavoprotein $\beta$-subunit & $\mathrm{C}$ & 0.26 & & - \\
\hline CAC2711 & bcd & Butyryl-CoA dehydrogenase & I & 0.28 & & - \\
\hline CAC2712 & $c r t$ & Enoyl-CoA hydratase, crotonase & I & 0.28 & & - \\
\hline CAC2873 & thlA & Thiolase & I & 0.31 & & - \\
\hline CAC3075 & buk & Butyrate kinase & $\mathrm{C}$ & 0.41 & & - \\
\hline CAC3076 & $p t b$ & Phosphate acetyltransferase & $\mathrm{C}$ & 0.35 & & - \\
\hline CAC3657 & $\operatorname{gap} N$ & NADP-GAPDH & $\mathrm{C}$ & 19.0 & 26.7 & + \\
\hline CAC3658 & & Conserved membrane protein, $\mathrm{SapB} / \mathrm{MtgC}$ family & $\mathrm{S}$ & 4.0 & 12.5 & - \\
\hline CAC3659 & $\operatorname{sam} X$ & $S$-Adenosylmethionine-dependent methyltransferase & $\mathrm{Q}$ & 2.1 & 4.7 & - \\
\hline \multicolumn{7}{|l|}{ Arginine biosynthesis } \\
\hline CAC0316 & $\arg F-\arg I$ & Ornithine carbomoyltransferase & $\mathrm{E}$ & & 0.15 & - \\
\hline CAC0376 & & $N$-Dimethylarginine dimethylaminohydrolase & $\mathrm{E}$ & 2.4 & 2.1 & - \\
\hline CAC0973 & $\arg G$ & Argininosuccinate synthase & $\mathrm{E}$ & & 0.12 & - \\
\hline CAC0974 & $\arg H$ & Argininosuccinate lyase & $\mathrm{E}$ & & 0.27 & - \\
\hline CAC2388 & $\arg D$ & $N$-Acetylornithine aminotransferase & $\mathrm{E}$ & & 0.11 & - \\
\hline CAC2389 & $\arg B$ & Acetylglutamate kinase & $\mathrm{E}$ & & 0.18 & - \\
\hline CAC2390 & $\operatorname{argC}$ & $N$-Acetyl- $\gamma$-glutamyl-phosphate reductase & $\mathrm{E}$ & & 0.29 & - \\
\hline CAC2391 & $\operatorname{argJ}$ & Ornithine acetyltransferase $/ N$-acetylglutamate synthase & $\mathrm{E}$ & & 0.31 & - \\
\hline
\end{tabular}

${ }^{a}$ CAC1547 to CAC1549, CAC1570 and CAC1571, CAC2448 to CAC2450, CAC2777 and CAC2778, CAC0447 and CAC0448, CAC0788 to CAC0791, CAC1029 to CAC1032, CAC1988 to CAC1990, CAC1991 to CAC1996, CAC0502 to CAC0503, CAC1391 to CAC1395, CAC3276 and CAC3277, CAC3288 to CAC3292, CAC3624 and CAC3625, CAP0162 to CAP0164, CAC0711 to CAC0713, CAC2458 and CAC2459, CAC2708 to CAC2712, CAC3075 and CAC3076, CAC3657 to CAC3659, CAC0973 and CAC0974, and CAC2388 to CAC2391 are genes that presumably form a transcriptional unit, respectively.

${ }^{b}$ As identified with Virtual Footprint software (48) (see Materials and Methods for details).

lase [CAC0711 to CAC0713]) are also moderately upregulated upon exposure to $\mathrm{O}_{2}$ (Table 2). The other highly activated gene translates into a protein which belongs to the Ni-containing carbon monoxide (CO) dehydrogenase (CODH) family, which includes actual CODHs and acetyl-CoA synthases of methanogenic and acetogenic organisms (12).

The PerR regulon of $\boldsymbol{C}$. acetobutylicum. A peroxide repressor-like (PerR) protein was recently shown to act as a central regulator of the $\mathrm{O}_{2}$ detoxification system of $C$. acetobutylicum, as the full activation of its regulon triggered aerobic survival and even limited growth (25). To find targets of PerR regulation and gain insight into the gene expression profile of an aerotolerant strain, the global transcription levels in perR-deleted cells and cells carrying the wild-type allele were compared. The complete absence of PerR resulted in the highly differential expression (more than threefold) of 87 genes. Of these genes, 48 were upregulated in the perR-deleted strain, which overlapped the oxygen stimulon of the wild-type strain. Nearly half of the genes that were induced in perR-deleted cells were also found to be highly expressed when the wild type was exposed to oxygen for $1 \mathrm{~h}$, while the remaining 28 genes were activated exclusively in the mutant strain (Fig. 1b). All differentially expressed genes (more-than-twofold change in transcription) of the PerR mutant were also assigned to functional categories using COG. Similar to the results obtained for the $\mathrm{O}_{2}$ stimulon, the majority of differentially expressed genes (37\% of the upregulated genes and $35 \%$ of the downregulated genes) encoded proteins that either could not be grouped or were of unknown function (cluster $\mathrm{X}$ ). Among the others, those involved in energy production and conversion (cluster $\mathrm{C}$; 
$11 \%$ upregulated genes and 5\% downregulated genes), amino acid transport and metabolism (cluster E; $7.5 \%$ and 22\%, respectively), and transcription (cluster K; $9 \%$ and 5\%, respectively) were highly represented in a $C$. acetobutylicum strain lacking PerR (Fig. 1a). The high number of 39 genes that were strictly downregulated (more than threefold) in the mutant strain demonstrated that PerR is essential for the expression of certain genes and/or might also have an activating role during anaerobic growth. Supporting these ideas, none of the lowerexpressed genes in the mutant were found to be as lesser transcribed during oxygen exposure of the wild type (Fig. 1b). Hence, the downregulation of genes in the perR mutant was apparently rather independent of the cell's oxygen response. There are only two exceptions to this point, which deserve some attention. The gene encoding CODH (CAC0116) was highly activated when wild-type cells were aerated, but the transcription of this gene was most strongly repressed in the PerR mutant strain (Table 2). Similarly, the gene encoding a glutathione peroxidase ( $b s a A 2$ [CAC1570]) was downregulated in the absence of PerR but was $\mathrm{O}_{2}$ inducible in wild-type cells, suggesting that an inactivated state of the PerR protein might be required in order to obtain a full expression of CAC0116 and $b s a A 2$ upon exposure to oxygen.

PerR represses $\mathrm{O}_{2}$ and $\mathrm{ROS}$ reduction. A first study of the role of PerR in $C$. acetobutylicum identified a flavodoxin (CAC2452), the FDP FprA1 (CAC1027), and, most prominently, the twin-gene-encoded reverse rubrerythrin Rbr3ARbr3B (CAC3598 and CAC35977) as being highly expressed in the absence of PerR (25). The transcripts of all these proteins were among the most dramatically induced ones. The highest expression values for the perR-deleted strain were determined for the genes and operons encoding Rbr3A-Rbr3B (CAC3598CAC3597), FprA1 (CAC1027), glutaredoxin (CAC2777), and NROR-FprA2-Dfx (CAC2448 to CAC2450). Fluorescence counts for these transcripts exceeded those for elongation factor $\mathrm{Tu}$ by a factor of up to 4.3 in the case of Rbr3A-Rbr3B, which was equivalent to saturation $(>80,000)$ when using highresolution scans (see Table S2 in the supplemental material). Therefore, the level of induction of these highly abundant transcripts might be underestimated (Table 2). Essentially all other genes previously reported as being members of anaerobic ROS detoxification or redox balance were also activated in the mutant, e.g., rubredoxin (CAC2778), the alkylhydroperoxidase Bcp (CAC3027), and a thiolperoxidase (CAC3306). Their induction in the absence of PerR even during anaerobiosis suggested that PerR is the key regulator that represses these proteins during the anaerobic growth of the wild type. Interestingly, the glutathione and thioredoxin antioxidant system, although activated by oxygen, seems to depend on an alternative regulatory mechanism, as no significant alterations in their transcript levels were detected in the PerR mutant strain (Table 2). Similar observations were made for the genes involved in nucleic acid repair or iron metabolism and/or transport, demonstrating that PerR is not the sole level of regulation and that as-yet-unidentified regulatory circuits exist. Only few genes of the central carbon pathways were differentially expressed in the perR mutant. These genes include the oxoacid ferredoxin oxidoreductase operon (CAC2458 and CAC2459), GapN (CAC3657), and the enzymes that catalyze the following two glycolytic reactions. a

$\begin{aligned} \text { TTAnnnATAATnnATTATnnnTAA } & \text { C. acetobutylicum } \\ \text { TTATAATn*ATTATAA } & \text { B. subtilis } \\ \text { AtTA } & \text { SATT* aureus }\end{aligned}$

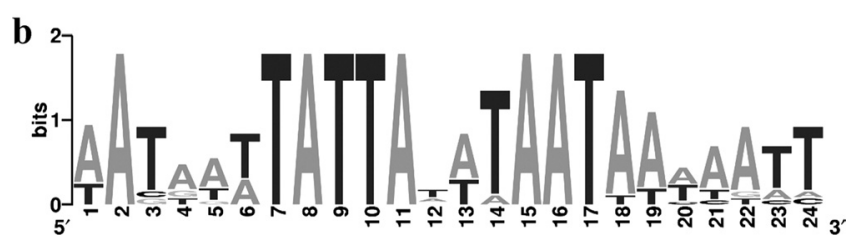

FIG. 2. PerR consensus-like conserved sequence motif in C. acetobutylicum. (a) Alignment of the reversed IR2 from C. acetobutylicum (24) to known PerR boxes from B. subtilis (8) and S. aureus (27). (b) Sequence logo representing conserved positions in the $C$. acetobutylicum PerR box identified upstream of commonly repressed genes (Table 2).

A total of four genes were strictly repressed ( $>10$-fold-lower expression) in the mutant strain and, hence, strongly dependent on the presence of a functional PerR protein for expression. These included two genes with a putative role in the biosynthesis or transport of siderophores (CAP0029 and CAP0030), the glutathione peroxidase BsaA2 (CAC1571), and CODH (CAC0116). Only the latter two genes were highly $\mathrm{O}_{2}$ inducible in wild-type cells. Many genes encoding enzymes for the biosynthesis of arginine were moderately downregulated in the mutant, which suggests that arginine could function as a source of intracellular nitric oxide (NO) in C. acetobutylicum. Consequently, enzymes involved in the inhibition of NO production ( $\mathrm{N}$-dimethylarginine dimethylaminohydrolase [CAC0376]) and FDPs as reductive NO scavengers (26) are upregulated in PerR mutant and in $\mathrm{O}_{2}$-exposed wild-type cells. In summary, PerR acts primarily as a repressor of an $\mathrm{O}_{2}$-responsive, large-scale ROS defense machinery but also targets those $\mathrm{O}_{2}$-sensitive bottlenecks that might be crucial for a continuous demand of NAD $(\mathrm{P}) \mathrm{H}$ and ATP.

Direct targets of PerR repression. An earlier study of the stress-dependent transcription of reverse rubrerythrins from $C$. acetobutylicum identified an inverted repeat of 24 nucleotides (IR2) in the $5^{\prime}$ untranslated region of $r b r 3 A$, for which a regulatory function was proposed (24). When reversed, this palindromic sequence shares a high level of similarity to the known consensus binding sequences of the peroxide repressor PerR from B. subtilis and Staphylococcus aureus (Fig. 2a). In the closely related facultative aerobe $B$. subtilis, PerR derepresses the transcription of multiple target genes upon its metal-catalyzed inactivation with $\mathrm{H}_{2} \mathrm{O}_{2}$ (40). To further support the idea that IR2 was the site of PerR regulation and to identify other potential target genes, a genome-wide search for IR2 was performed using Virtual Footprint software (48). When using exclusively the palindromic nucleotides and allowing a single mismatch, a total of 10 genes that carried a potential PerR box within 200 bp of their start codon were found. Nine of them were among those with the highest level of induction in the perR mutant, including the ones encoding FprA1, the entire $\mathrm{O}_{2}$-responsive operon with NROR, FprA2, and Dfx, the glutaredoxin-rubredoxin operon, and both subunits of an oxoacid-ferredoxin oxidoreductase (Table 2). The $\mathrm{O}_{2}$-induced gapN gene, encoding a nonphosphorylating NADP-dependent GAPDH, was also highly expressed in the 

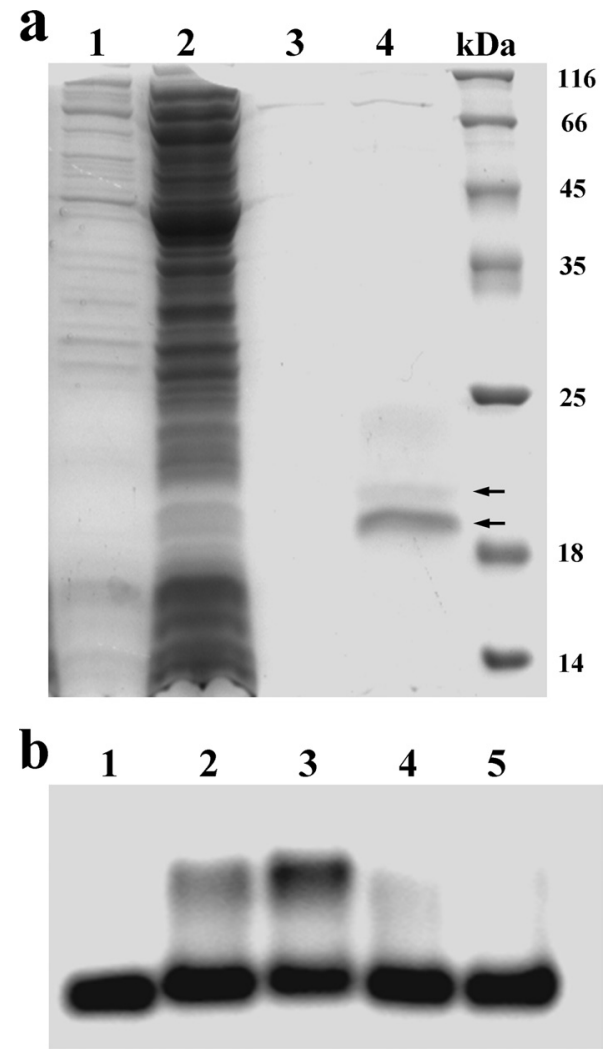

FIG. 3. Interaction of purified PerR with the $r b r 3 A-r b r 3 B$ promoter region. (a) Coomassie-stained SDS-polyacrylamide gel electrophoresis $(12.5 \%)$. Lanes 1 and 2, 10 and $50 \mu \mathrm{g}$ of crude extract from $E$. coli cells expressing PerR $\mathrm{C}_{\mathrm{Cac}}$; lanes 3 and 4 , purification fractions. $\mathrm{kDa}$ indicates the molecular mass marker. The two bands (arrows) are likely to represent two different metal-bound states of PerR as described previously for the B. subtilis peptide (41). (b) Electrophoretic mobility shift assays were carried out with $12.5 \mathrm{nM}$ of the $r b r 3 A-r b r 3 B$ promoter fragment. Fragments were incubated without protein (lane 1) or with $35 \mathrm{nM}$ (lane 2) and $50 \mathrm{nM}$ (lanes 3 to 5) of purified PerR. As negative controls, $25 \mathrm{nM}$ (lane 4) or $50 \mathrm{nM}$ (lane 5) of an unlabeled promoter fragment was also added to the reaction mixtures.

absence of PerR and preceded by a PerR box with three mismatches. Several conserved nucleotide positions were detected for this regulatory module, which could be illustrated as a sequence logo (Fig. 2b).

PerR binds to the $r b r 3 A-r b r 3 B$ promoter region. To determine if the clostridial PerR homologue directly interacts with the promoter region of $r b r 3 A$, its gene was heterologously overexpressed in $E$. coli cells. The PerR-encoding ORF CAC2634 was cloned into plasmid pT to obtain a fusion protein with C-terminal Strep-tagII. SDS-polyacrylamide gel electrophoresis of the purified fraction yielded two bands, corresponding roughly to the calculated molecular mass of the Strep-tag fusion protein monomer of $17.1 \mathrm{kDa}$. The small size variation as well as a faint upper band might reflect different oxidation states, which were previously observed for the $B$. subtilis peptide (41) (Fig. 3a). The purified protein was incubated with a labeled DNA fragment of the $\operatorname{rbr} 3 A$ promoter region covering the last $235 \mathrm{bp}$ of the $5^{\prime}$ untranslated region and IR2. When these reaction mixtures were applied for gel electrophoresis, the mobility of this fragment was

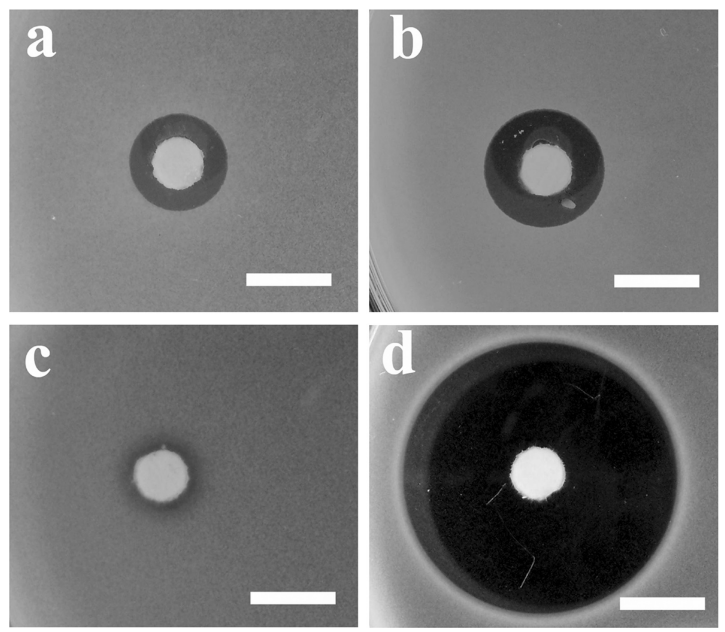

FIG. 4. Zone-of-inhibition assay for different B. subtilis strains with $\mathrm{H}_{2} \mathrm{O}_{2}$. Mid-logarithmic-phase cells were added to prewarmed LB agar and poured into petri dishes, and a disk with $5 \mu \mathrm{l}$ of $1 \mathrm{M} \mathrm{H}_{2} \mathrm{O}_{2}$ was placed onto the agar plates. Growth and zones of inhibition for each strain were monitored following overnight incubation at $30^{\circ} \mathrm{C}$. White

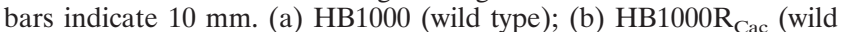
type expressing PerR $\mathrm{Cac}_{\mathrm{Ca}}$ ); (c) HB0509 (B. subtilis perR mutant); (d) $\mathrm{HB} 0509 \mathrm{R}_{\mathrm{Cac}}$ (B. subtilis perR mutant expressing PerR $\left.\mathrm{R}_{\mathrm{Cac}}\right)$.

reduced, depending on the amount of PerR in the assay (Fig. 3b, lanes 1 to 3 ). This shift in DNA mobility could be reversed stepwise following the addition of unlabeled fragment, giving evidence that the binding of PerR was DNA specific (Fig. 3b, lanes 4 and 5).

PerR from $C$. acetobutylicum responds to $\mathrm{H}_{2} \mathrm{O}_{2}$. The conserved binding motif and interaction with the promoter region of $r b r 3 A-r b r 3 B$ suggested that the mode of PerR regulation is conserved in $C$. acetobutylicum albeit with different target genes compared to those of facultative aerobes. To monitor PerR binding in vivo and show that the PerR protein of $C$. acetobutylicum might be a peroxide sensor rather than a direct $\mathrm{O}_{2}$ sensor, complementational studies were performed. The clostridial PerR protein was expressed from a xylose-inducible promoter in wild-type $B$. subtilis and a strain lacking a functional perR gene. Subsequently, their sensitivity to $\mathrm{H}_{2} \mathrm{O}_{2}$ was monitored in a zone-of-inhibition assay (Fig. 4). In the presence of xylose, the wild-type B. subtilis strain expressing PerR $_{\mathrm{Cac}}$ differed only marginally from its parent in its sensitivity to $\mathrm{H}_{2} \mathrm{O}_{2}$, which might reflect the higher affinity of $B$. subtilis PerR (PerR $\left.\mathrm{Bsu}_{\mathrm{Bu}}\right)$ for its own binding site (Fig. 4a and b). $B$. subtilis cells lacking their own perR gene are hyperresistant to $\mathrm{H}_{2} \mathrm{O}_{2}$ due to an increased production of defense proteins (7). Following the expression of PerR $\mathrm{Cac}_{\text {ac }}$, this hyperresistant phenotype was converted to a hypersensitive one, giving evidence that the protein from $C$. acetobutylicum can indeed acts as a repressor despite aerobic growth (Fig. $4 c$ and d). The peroxide sensitivities of all strains were reflected largely by their catalase activities during growth in aerobic liquid cultures. Wild-type cells showed normal levels of catalase that were even moderately reduced when expressing PerR $_{\text {Cac }}$, but catalase was nearly 100 -fold more active in the perR mutant strain (Fig. 5). When, in turn, the clostridial peptide was produced in the cells, catalase activity was reduced by more than 


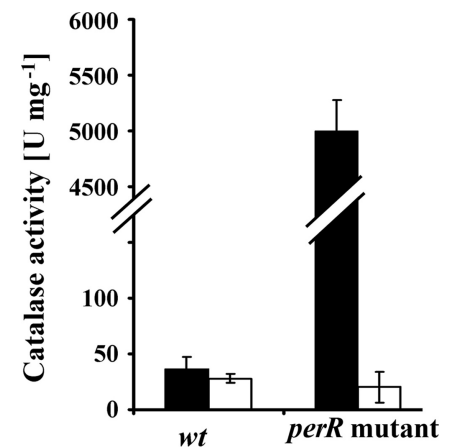

FIG. 5. Catalase activities in a PerR $\mathrm{Cac}_{\text {-complemented B. subtilis }}$ strain. Catalase was measured in crude extracts either from cells that

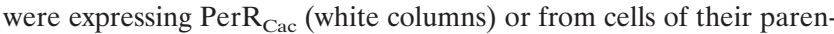
tal strains lacking the clostridial gene (black columns). Names below the columns indicate the relevant $B$. subtilis genotypes, which were either wild type (wt) or perR mutants.

200-fold, to levels far below those of wild-type cells (Fig. 5). Low doses of $\mathrm{H}_{2} \mathrm{O}_{2}$ were able to partially restore catalase activity (data not shown), indicating that the key regulator of oxygen defense in $C$. acetobutylicum senses intracellular peroxide levels rather than molecular $\mathrm{O}_{2}$.

\section{DISCUSSION}

The finding that oxygen-sensitive enzymes are widely used as central components in the metabolism of anaerobes as well as the existence of a robust defense system has led to a refinement of the traditional model of obligate anaerobiosis. An energy metabolism that relies exclusively on the fermentation of highly reduced substrates demands enzymes with low redox potentials and, thus, an environment that is predominantly anaerobic. C. acetobutylicum flourishes under fully anaerobic conditions and even maintains growth at a reduced rate when the influx of oxygen is compensated by its continuous reduction (35). Only when dissolved oxygen accumulates are central metabolic enzymes like PFOR wrecked at a rate at which metabolism is halted and viability decreases. In a natural environment, exposure to $\mathrm{O}_{2}$ might occur gradually and, thus, allows an efficient adaptation (31). This has just recently been shown for a number of other bacteria from a diverse group of anaerobes, e.g., Bacteroides fragilis, D. vulgaris, and Thermotoga maritima $(3,42,47)$. The experimental setup presented here was designed so that the level of influx of $\mathrm{O}_{2}$ was low enough to ensure metabolic activity but sufficient to generate substantial cellular damage. Microaerobic growth as well as the deletion of a central regulator in oxidative stress resulted in global changes in gene expression under $\mathrm{O}_{2}$, leading to a preliminary model on how $C$. acetobutylicum attempts to combine $\mathrm{O}_{2} / \mathrm{ROS}$ removal, damage repair, and adjustments in central energy metabolism to avoid paralysis (Fig. 6).

The production of proteins involved in detoxification and cellular redox balance was most drastically activated, which was expected, as the upregulation of these components was observed recently for a number of bacteria that are considered to be anaerobes $(42,47,66)$. The massive expression of all components of the proposed oxygen and ROS detoxification

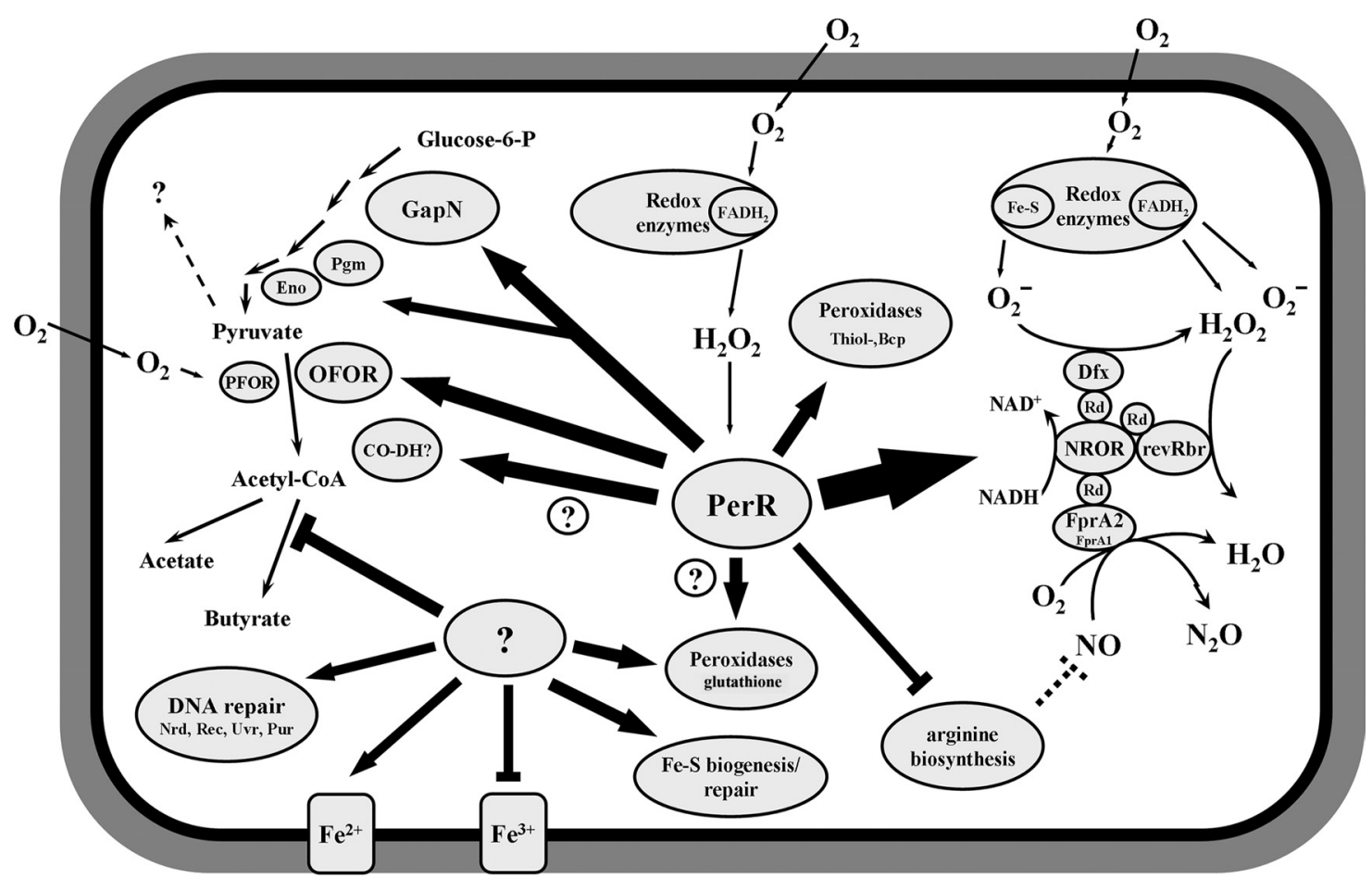

FIG. 6. Model of the transcriptional response of C. acetobutylicum to $\mathrm{O}_{2}$. Differentially regulated genes are represented as encoded proteins or as functional groups and are highlighted in gray. Abbreviations used are the same as those shown in Table 2. Arrows illustrate upregulation (normal) or downregulation (blunt) at direct or indirect regulatory targets and their relative expression levels upon exposure to $\mathrm{O}_{2}$. Circled question marks indicate potentially activated regulatory targets of $\mathrm{PerR}$. $\mathrm{FADH}_{2}$, reduced flavin adenine dinucleotide. 
system, which involves FDPs, Dfx, NROR, rubredoxin, and reverse rubrerythrins, emphasized its vital role in survival. Consequently, all of these components were found be the primary targets of PerR repression, as they were overexpressed in the perR-deleted strain and shared a common regulatory motif. Thus, it seems likely that PerR acts as a hypersensitive regulator designed to activate these genes even in the presence of traces of oxygen. The acute induction of this system in a natural environment will also support the restoration of anaerobiosis by a complete uptake of residual oxygen.

PFOR could be a major bottleneck in glucose degradation and acetyl-CoA production under microaerobic conditions. An enzyme with a higher resistance to oxidative inactivation would clearly be of advantage during oxygen exposure. At this time, induced oxoacid-ferredoxin oxidoreductase has not been functionally characterized, but the use of similar enzymes in aerobic archaea makes it tempting to speculate that a replacement occurs under these conditions $(49,70)$. A similar mechanism could be postulated for the nonphosphorylating GAPDH $(\mathrm{GapN})$, as an increased resistance to $\mathrm{H}_{2} \mathrm{O}_{2}$ has been shown for the homologous protein from the aerotolerant anaerobe Streptococcus mutans (2). Interestingly, oxoacid-ferredoxin oxidoreductase and GapN seem to be two of the very few proteins that function outside the detoxification system and are still subject to direct PerR repression. This indicates their significance during the early response to oxygen, while glutathione- and thioredoxin-dependent rescue systems were PerR independent and could belong to circuits that protect from persistent exposure to oxidative conditions.

In an oxidizing environment, $C$. acetobutylicum seems to direct its electron flow toward the higher-oxidized product acetate or acetone. This is in agreement with a slightly increased level of acetate production by $C$. acetobutylicum upon exposure to $\mathrm{O}_{2}$, which was observed during a previously reported investigation (51). The results presented here demonstrate that essentially all genes in the formation of butyrate downstream from acetyl-CoA are downregulated, suggesting that this pathway is less favorable when an oxidized dinucleotide pool is regenerated during the reduction of $\mathrm{O}_{2}$ and ROS. At the same time, we observed a moderate upregulation of the sol operon, which might integrate in the larger general stress network, finally inducing solvent formation and sporulation.

Another enzyme with highly activated expression upon exposure to $\mathrm{O}_{2}$ is a member of the CODH protein family. When the amino acid sequences of the oxygen-induced proteins from C. acetobutylicum were compared to the known homologues of Carboxydothermus hydrogenoformans, the clostridial peptide shows the lowest similarity to the acetyl-CoA synthase subunits (data not shown). Furthermore, the absence of genes encoding any other subunit of acetyl-CoA synthases makes it rather unlikely that this protein is involved in $\mathrm{CO}_{2}$-dependent acetyl$\mathrm{CoA}$ formation. A role for these proteins in the oxidative stress response has not been established, but a homologue from $C$. hydrogenoformans was speculated to function in ROS detoxification due to its genomic position in an operon with rubrerythrin and NROR (69). Furthermore, it cannot be excluded at this point that the clostridial protein also serves a protective function in the hydrogen production of this organism. $\mathrm{H}_{2}$-evolving hydrogenase $\mathrm{A} 1$ (HydA1) of $C$. acetobutylicum is highly sensitive to oxygen-dependent inactivation (11,
20). While low doses of molecular $\mathrm{O}_{2}$ lead to irreversibly damaged enzymes, $\mathrm{CO}$ was previously shown to act as a competitive inhibitor that antagonizes $\mathrm{O}_{2}$ and can greatly reduce the hydrogenase inactivation state $(16,43)$. The completely opposite expression patterns of this protein in both strains partially support this idea: the gene encoding CODH showed a high level of activation when the wild type was exposed to $\mathrm{O}_{2}$ but the lowest level of transcription in anaerobic perR-deleted cells. The opposed expression of this gene in both strains addresses another interesting issue of PerR regulation. It does not seem unlikely that PerR could also function as a gene activator in its oxidized form via an as-yet-undefined mechanism. Direct gene activation by PerR was previously seen for the B. subtilis srf $A$ operon (21). ROS-induced transcriptional activation, although previously assigned to SoxR (OxyR), was more recently also demonstrated for the Borellia oxidative stress regulator BosR, a homologue of B. subtilis PerR (4, 23, 71).

The regulatory role in the peroxide stimulon as well as the mechanism of inactivation by $\mathrm{H}_{2} \mathrm{O}_{2}$ in a Fenton-type reaction have been thoroughly described for the B. subtilis peptide (7, $19,40)$. In the anaerobe $C$. acetobutylicum, the external addition of $\mathrm{H}_{2} \mathrm{O}_{2}$ was not required to activate the organism's PerR regulon, while even low doses of $\mathrm{O}_{2}$ were an adequate stimulus. The complementation of a B. subtilis strain lacking functional PerR with PerR $\mathrm{Cac}_{\text {ac }}$ provided evidence that the clostridial protein was a fully functional homologue of PerR in vivo. The presence of the clostridial peptide in a strain lacking $\operatorname{PerR}_{\mathrm{Bsu}}$ repressed the expression of oxidative stress proteins during aerobic growth and resulted in a peroxide-hypersensitive phenotype. Low doses of external $\mathrm{H}_{2} \mathrm{O}_{2}$ inactivated PerR $\mathrm{Cac}_{\mathrm{Cac}}$ and derepressed catalase. However, as indicated from the proposed regulatory sequence motif for $C$. acetobutylicum, the level of specificity of $\operatorname{PerR}_{\mathrm{Cac}}$ for the $B$. subtilis PerR boxes seems to be reduced. When PerR $\mathrm{Cac}_{\text {ac }}$ was expressed in wildtype $B$. subtilis cells, only a small increase in $\mathrm{H}_{2} \mathrm{O}_{2}$ sensitivity was determined, presumably as a result of the preferred bind-

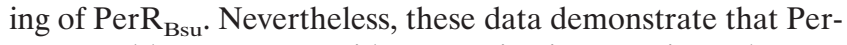
$\mathrm{R}_{\mathrm{Cac}}$ could act as a peroxide sensor in vivo. Previous observations estimated that upon aeration, the intracellular $\mathrm{H}_{2} \mathrm{O}_{2}$ concentration experienced by strict anaerobes could be substantially higher than that in aerobes due to the oxidation of low-potential flavoenzymes (30). Especially for a strict anaerobe, it seems beneficial that the presence of $\mathrm{O}_{2}$ is indirectly perceived by elevated levels of $\mathrm{H}_{2} \mathrm{O}_{2}$. The use of $\mathrm{H}_{2} \mathrm{O}_{2}$ as a signal molecule also allows the integration of metabolic activity, which determines the extent of ROS production. Consequently, C. acetobutylicum does not rely solely on their removal but also attempts to adapt its fermentation metabolism to lesser-reduced environments (Fig. 6). However, a broad understanding of its physiology during $\mathrm{O}_{2}$ exposure will require further investigations, especially with respect to the biotechnological potential of this organism.

\section{ACKNOWLEDGMENTS}

This work was supported in part by SysMO project COSMIC (http: //www.sysmo.net) (to A.E., R.-J.F., and H.B.).

We thank John D. Helmann and Achmed Gaballa from the Department of Microbiology at Cornell University for B. subtilis strains HB1000 and HB0509. We are also grateful to Jim Imlay for helpful comments on the manuscript. 


\section{REFERENCES}

1. Anderson, L. A., E. McNairn, T. Lubke, R. N. Pau, and D. H. Boxer. 2000 ModE-dependent molybdate regulation of the molybdenum cofactor operon moa in Escherichia coli. J. Bacteriol. 182:7035-7043. (Erratum, 184:4326, 2002.)

2. Arutyunov, D. Y., and V. I. Muronetz. 2003. The activation of glycolysis performed by the non-phosphorylating glyceraldehyde-3-phosphate dehydrogenase in the model system. Biochem. Biophys. Res. Commun. 300:149154.

3. Baughn, A. D., and M. H. Malamy. 2004. The strict anaerobe Bacteroides fragilis grows in and benefits from nanomolar concentrations of oxygen. Nature 427:441-444.

4. Boylan, J. A., J. E. Posey, and F. C. Gherardini. 2003. Borrelia oxidative stress response regulator, BosR: a distinctive $\mathrm{Zn}$-dependent transcriptional activator. Proc. Natl. Acad. Sci. USA 100:11684-11689.

5. Bradford, M. M. 1976. A rapid and sensitive method for the quantitation of microgram quantities of protein utilizing the principle of protein-dye binding. Anal. Biochem. 72:248-254.

6. Brioukhanov, A. L., and A. I. Netrusov. 2007. Aerotolerance of strictly anaerobic microorganisms and factors of defense against oxidative stress: a review. Appl. Biochem. Microbiol. 43:567-582.

7. Bsat, N., A. Herbig, L. Casillas-Martinez, P. Setlow, and J. D. Helmann. 1998. Bacillus subtilis contains multiple Fur homologues: identification of the iron uptake (Fur) and peroxide regulon (PerR) repressors. Mol. Microbiol. 29:189-198.

8. Chen, L., L. Keramati, and J. D. Helmann. 1995. Coordinate regulation of Bacillus subtilis peroxide stress genes by hydrogen peroxide and metal ions. Proc. Natl. Acad. Sci. USA 92:8190-8194.

9. Crooks, G. E., G. Hon, J. M. Chandonia, and S. E. Brenner. 2004. WebLogo: a sequence logo generator. Genome Res. 14:1188-1190.

10. Cutting, S. M., and P. Youngman. 1994. Gene transfer in gram-positive bacteria, p. 348-364. In P. Gerhardt, R. G. E. Murray, W. A. Wood, and N. R. Krieg (ed.), Methods for general and molecular bacteriology. ASM Press, Washington, DC.

11. Demuez, M., L. Cournac, O. Guerrini, P. Soucaille, and L. Girbal. 2007. Complete activity profile of Clostridium acetobutylicum [FeFe]-hydrogenase and kinetic parameters for endogenous redox partners. FEMS Microbiol. Lett. 275:113-121.

12. Drennan, C. L., T. I. Doukov, and S. W. Ragsdale. 2004. The metalloclusters of carbon monoxide dehydrogenase/acetyl-CoA synthase: a story in pictures. J. Biol. Inorg. Chem. 9:511-515.

13. Dürre, P., and H. Bahl. 1996. Microbial production of acetone/butanol/ isopropanol, p. 229-268. In H. J. Rehm, G. Reed, A. Pühler, and P. Stadler (ed.), Biotechnology: a multi-volume comprehensive treatise, vol. 1, 2nd ed. VCH Verlagsgesellschaft, Weinheim, Germany.

14. Dürre, P. 2007. Biobutanol: an attractive biofuel. Biotechnol. J. 2:1525-1534

15. Dürre, P. 2008. Fermentative butanol production: bulk chemical and biofuel. Ann. N. Y. Acad. Sci. 1125:353-362.

16. Erbes, D. L., D. King, and M. Gibbs. 1979. Inactivation of hydrogenase in cell-free extracts and whole cells of Chlamydomonas reinhardi by oxygen. Plant Physiol. 63:1138-1142.

17. Fischer, R. J., S. Oehmcke, U. Meyer, M. Mix, K. Schwarz, T. Fiedler, and H. Bahl. 2006. Transcription of the pst operon of Clostridium acetobutylicum is dependent on phosphate concentration and pH. J. Bacteriol. 188:54695478 .

18. Fitzpatrick, J. M., D. A. Johnston, G. W. Williams, D. J. Williams, T. C. Freeman, D. W. Dunnea, and K. F. Hoffmann. 2005. An oligonucleotide microarray for transcriptome analysis of Schistosoma mansoni and its application/use to investigate gender-associated gene expression. Mol. Biochem. Parasitol. 141:1-13.

19. Fuangthong, M., and J. D. Helmann. 2003. Recognition of DNA by three ferric uptake regulator (Fur) homologs in Bacillus subtilis. J. Bacteriol. 185: 6348-6357.

20. Girbal, L., G. von Abendroth, M. Winkler, P. M. Benton, I. Meynial-Salles, C. Croux, J. W. Peters, T. Happe, and P. Soucaille. 2005. Homologous and heterologous overexpression in Clostridium acetobutylicum and characterization of purified clostridial and algal Fe-only hydrogenases with high specific activities. Appl. Environ. Microbiol. 71:2777-2781.

21. Hayashi, K., T. Ohsawa, K. Kobayashi, N. Ogasawara, and M. Ogura. 2005. The $\mathrm{H}_{2} \mathrm{O}_{2}$ stress-responsive regulator PerR positively regulates $\operatorname{sif} A$ expression in Bacillus subtilis. J. Bacteriol. 187:6659-6667.

22. Helmann, J. D., M. F. W. Wu, A. Gaballa, P. A. Kobel, M. M. Morshedi, P. Fawcett, and C. Paddon. 2003. The global transcriptional response of Bacillus subtilis to peroxide stress is coordinated by three transcription factors. J. Bacteriol. 185:243-253.

23. Hidalgo, E., H. Ding, and B. Demple. 1997. Redox signal transduction: mutations shifting [2Fe-2S] centers of the SoxR sensor-regulator to the oxidized form. Cell 88:121-129.

24. Hillmann, F., R. J. Fischer, and H. Bahl. 2006. The rubrerythrin-like protein Hsp21 is a general stress protein. Arch. Microbiol. 185:270-276.

25. Hillmann, F., R. J. Fischer, F. Saint-Prix, L. Girbal, and H. Bahl. 2008. PerR acts as a switch for oxygen tolerance in the strict anaerobe Clostridium acetobutylicum. Mol. Microbiol. 68:848-860.

26. Hillmann, F., R. J. Fischer, J. D. Caranto, A. Mot, D. M. Kurtz, Jr., and H. Bahl. 2009. Reductive dioxygen scavenging of flavodiiron proteins of Clostridium acetobutylicum. FEBS Lett. 583:241-245.

27. Horsburgh, M. J., M. O. Clements, H. Crossley, A. Ingham, and S. J. Foster. 2001. PerR controls oxidative stress resistance and iron storage proteins and is required for virulence in Staphylococcus aureus. Infect. Immun. 69:37443754.

28. Iddar, A., F. Valverde, A. Serrano, and A. Soukri. 2002. Expression, purification, and characterization of recombinant nonphosphorylating NADPdependent glyceraldehyde-3-phosphate dehydrogenase from Clostridium acetobutylicum. Protein Expr. Purif. 25:519-526.

29. Imlay, J. A. 2006. Iron-sulphur clusters and the problem with oxygen. Mol. Microbiol. 59:1073-1082.

30. Imlay, J. A. 2003. Pathways of oxidative damage. Annu. Rev. Microbiol. $\mathbf{5 7 : 3 9 5 - 4 1 8 . ~}$

31. Imlay, J. A. 2008. How obligatory is anaerobiosis? Mol. Microbiol. 68:801804.

32. Imlay, J. A. 2008. Cellular defenses against superoxide and hydrogen peroxide. Annu. Rev. Biochem. 77:755-776.

33. Jenney, F. E., Jr., M. F. J. M. Verhagen, C. Xiaoyuan, and M. W. W. Adams. 1999. Anaerobic microbes: oxygen detoxification without superoxide dismutase. Science 286:306-309.

34. Jones, S. W., C. J. Paredes, B. Tracy, N. Cheng, R. Sillers, R. S. Senger, and E. T. Papoutsakis. 2008. The transcriptional program underlying the physiology of clostridial sporulation. Genome Biol. 7:R114.

35. Kawasaki, S., J. Ishikura, Y. Watamura, M. Ono, and Y. Niimura. 2004 Identification of $\mathrm{O}_{2}$-induced peptides in the obligatory anaerobe Clostridium acetobutylicum. FEBS Lett. 571:21-25.

36. Kawasaki, S., Y. Watamura, M. Ono, T. Watanabe, K. Takeda, and Y. Niimura. 2005. Adaptive responses to oxygen stress in obligatory anaerobes Clostridium acetobutylicum and Clostridium aminovalericum. Appl. Environ. Microbiol. 71:8442-8450.

37. Kim, L., A. Mogk, and W. Schumann. 1996. A xylose-inducible Bacillus subtilis integration vector and its application. Gene 181:71-76.

38. Kisher, C., H. Schindelin, and D. C. Rees. 1997. Molybdenum-cofactorcontaining enzymes: structure and mechanism. Annu. Rev. Biochem. 66: 233-267.

39. Lee, J., H. Yun, A. M. Feist, B. Ø. Palsson, and S. Y. Lee. 2008. Genomescale reconstruction and in silico analysis of the Clostridium acetobutylicum ATCC 824 metabolic network. Appl. Microbiol. Biotechnol. 80:849-862.

40. Lee, J. W., and J. D. Helmann. 2006. The PerR transcription factor senses $\mathrm{H}_{2} \mathrm{O}_{2}$ by metal-catalysed histidine oxidation. Nature 440:363-367.

41. Lee, J. W., and J. D. Helmann. 2006. Biochemical characterization of the structural $\mathrm{Zn}^{2+}$ site in the Bacillus subtilis peroxide sensor PerR. J. Biol. Chem. 281:23567-23578.

42. LeFourn, C., M. L. Fardeau, B. Ollivier, E. Lojou, and A. Dolla. 2008. The hyperthermophilic anaerobe Thermotoga maritima is able to cope with limited amount of oxygen: insights into its defence strategies. Environ. Microbiol. 10:1877-1887.

43. Maness, P. C., S. Smolinski, A. C. Dillon, M. J. Heben, and P. F. Weaver. 2002. Characterization of the oxygen tolerance of a hydrogenase linked to a carbon monoxide oxidation pathway in Rubrivivax gelatinosus. Appl. Environ. Microbiol. 68:2633-2636.

44. May, A., F. Hillmann, O. Riebe, R. J. Fischer, and H. Bahl. 2004. A rubrerythrin-like oxidative stress protein of Clostridium acetobutylicum is encoded by a duplicated gene and identical to the heat shock protein Hsp21. FEMS Microbiol. Lett. 238:249-254.

45. McCord, J. M., B. B. Keele, Jr., and I. Fridovich. 1971. An enzyme-based theory of obligate anaerobiosis: the physiological function of superoxide dismutase. Proc. Natl. Acad. Sci. USA 68:1024-1027.

46. Meinecke, B., J. Bertram, and G. Gottschalk. 1989. Purification and characterization of the pyruvate-ferredoxin oxidoreductase from Clostridium acetobutylicum. Arch. Microbiol. 152:244-250.

47. Mukhopadhyay, A., A. M. Redding, M. P. Joachimiak, A. P. Arkin, S. E. Borglin, P. S. Dehal, R. Chakraborty, J. T. Geller, T. C. Hazen, Q. He, D. C. Joyner, V. J. Martin, J. D. Wall, Z. K. Yang, J. Zhou, and J. D. Keasling. 2007. Cell-wide responses to low-oxygen exposure in Desulfovibrio vulgaris Hildenborough. J. Bacteriol. 189:5996-6010.

48. Münch, R., K. Hiller, H. Barg, D. Heldt, S. Linz, E. Wingender, and D. Jahn. 2003. PRODORIC: prokaryotic database of gene regulation. Nucleic Acids Res. 31:266-269.

49. Nishizawa, Y., T. Yabuki, E. Fukuda, and T. Wakagi. 2005. Gene expression and characterization of two 2-oxoacid:ferredoxin oxidoreductases from Aeropyrum pernix K1. FEBS Lett. 579:2319-2322.

50. Nölling, J., G. Breton, M. V. Omelchenko, K. S. Makarova, Q. Zeng, R. Gibson, H. M. Lee, J. Dubios, D. Qiu, J. Hitti, GTC Sequencing Center Production, Finishing, and Bioinformatics Teams, Y. I. Wolf, R. L. Tatusov, F. Sabathe, L. Doucette-Stamm, P. Soucaille, M. J. Daly, G. N. Bennett, E. V. Koonin, and D. R. Smith. 2001. Genome sequence and comparative analysis 
of the solvent-producing bacterium Clostridium acetobutylicum. J. Bacteriol 183:4823-4838.

51. O'Brien, R. W., and J. G. Morris. 1971. Oxygen and the growth and metabolism of Clostridium acetobutylicum. J. Gen. Microbiol. 68:307-318.

52. Pan, N., and J. A. Imlay. 2001. How does oxygen inhibit central metabolism in the obligate anaerobe Bacteroides thetaiotaomicron. Mol. Microbiol. 39: 1562-1571.

53. Papoutsakis, E. T. 2008. Engineering solventogenic clostridia. Curr. Opin. Biotechnol. 19:420-429.

54. Paredes, C. J., R. S. Senger, I. S. Spath, J. R. Borden, R. Sillers, and E. T. Papoutsakis. 2007. A general framework for designing and validating oli gomer-based DNA microarrays and its application to Clostridium acetobutylicum. Appl. Environ. Microbiol. 73:4631-4638.

55. Petitdemange, H., R. Marczak, H. Blusson, and R. Gay. 1979. Isolation and properties of reduced nicotinamide adenine dinucleotide rubredoxin oxidoreductase of Clostridium acetobutylicum. Biochem. Biophys. Res. Commun. 91:1258-1265.

56. Riebe, O., R. J. Fischer, and H. Bahl. 2007. Desulfoferrodoxin from Clos tridium acetobutylicum functions as a superoxide reductase. FEBS Lett. 581: 5605-5610.

57. Riebe, O., R. J. Fischer, D. A. Wampler, D. M. Kurtz, Jr., and H. Bahl. 2009 Pathway for $\mathrm{H}_{2} \mathrm{O}_{2}$ and $\mathrm{O}_{2}$ detoxification in Clostridium acetobutylicum. Microbiology 155:16-24.

58. Rodionov, D. A., I. Dubchak, A. Arkin, E. Alm, and M. S. Gelfand. 2004 Reconstruction of regulatory and metabolic pathways in metal-reducing $\delta$ proteobacteria. Genome Biol. 5:R90.

59. Sawers, G., and G. Watson. 1998. A glycyl radical solution:oxygen-dependent interconversion of pyruvate formate lyase. Mol. Microbiol. 29:945-954.

60. Schmidt, T. G., and A. Skerra. 2007. The Strep-tag system for one-step purification and high-affinity detection or capturing of proteins. Nat. Protoc. 2:1528-1535.

61. Senger, R. S., and E. T. Papoutsakis. 2008. Genome-scale model for Clos tridium acetobutylicum. Part I. Metabolic network resolution and analysis. Biotechnol. Bioeng. 101:1036-1052.

62. Shah, V. K., and W. J. Brill. 1977. Isolation of an iron-molybdenum cofactor from nitrogenase. Proc. Natl. Acad. Sci. USA 74:3249-3253.
63. Shaw, D. J., D. W. Rice, and J. R. Guest. 1983. Homology between CAP and Fnr, a regulator of anaerobic respiration in Escherichia coli. J. Mol. Biol. 166:241-247.

64. Sillers, R., A. Chow, B. Tracy, and E. T. Papoutsakis. 2008. Metabolic engineering of the non-sporulating, non-solventogenic Clostridium acetobutylicum strain M5 to produce butanol without acetone demonstrate the robustness of the acid-formation pathways and the importance of the electron balance. Metab. Eng. 10:321-332.

65. Soucaille, P., R. Figge, and C. Croux. April 2008. Process for chromosomal integration and DNA sequence replacement in clostridia. International patent application WO/2008/040387.

66. Sund, C. J., E. R. Rocha, A. O. Tzianabos, W. G. Wells, J. M. Gee, M. A. Reott, D. P. O'Rourke, and C. J. Smith. 2008. The Bacteroides fragilis transcriptome response to oxygen and $\mathrm{H}_{2} \mathrm{O}_{2}$ : the role of OxyR and its effect on survival and virulence. Mol. Microbiol. 67:129-142. (Erratum, 68:1340, 2008.)

67. Tatusov, R. L., M. Y. Galperin, D. A. Natale, and E. V. Koonin. 2000. The COG database: a tool for genome-scale analysis of protein functions and evolution. Nucleic Acids Res. 28:33-36.

68. Weinberg, M. V., F. E. Jenney, Jr., X. Cui, and M. M. W. Adams. 2004 Rubrerythrin from the hyperthermophilic archaeon Pyrococcus furiosus is a rubredoxin-dependent, iron-containing peroxidase. J. Bacteriol. 186:78887895.

69. Wu, M., Q. Ren, A. S. Durkin, S. C. Daugherty, L. M. Brinkac, R. J. Dodson, R. Madupu, S. A. Sullivan, J. F. Kolonay, D. H. Haft, W. C. Nelson, L. J. Tallon, K. M. Jones, L. E. Ulrich, J. M. Gonzalez, I. B. Zhulin, F. T. Robb, and J. A. Eisen. 2005. Life in hot carbon monoxide: the complete genome sequence of Carboxydothermus hydrogenoformans Z-2901. PLoS Genet. 1:e65. (Erratum, 2:e60, 2006.)

70. Zhang, Q., T. Iwasaki, T. Wakagi, and T. Oshima. 1996. 2-Oxoacid:ferredoxin oxidoreductase from the thermoacidophilic archaeon Sulfolobus sp. strain 7. J. Biochem. 120:587-599.

71. Zheng, M., F. Aslund, and G. Storz. 1998. Activation of the OxyR transcription factor by reversible disulfide bond formation. Science 279:1718-1721. 